\title{
New species of the genus Trochoguembelitria from the lowermost Danian of Tunisia - biostratigraphic and evolutionary implications in planktonic foraminifera
}

\author{
by
}

\author{
Ignacio Arenillas, José Antonio Arz and Carolina Náñez
}

with 4 plates, 7 text-figures and 1 table

\begin{abstract}
Two lineages of primitive trochospiral species emerged in the earliest Danian after the Cretaceous/Paleogene ( $\mathrm{K} / \mathrm{Pg}$ ) mass extinction event, one exhibiting a smooth wall texture with mural pores and the other, a pustulate to rugose wall texture consisting of blunt pustules and small rugosities, imperforate or with decentred pores, and scattered pore-mounds. This evolutionary scenario is based on Tunisian sections, particularly the El Kef section, whose continuity, completeness, abundance and excellent preservation of the foraminifera make it the best locality worldwide for analyzing the taxonomy and evolution of the early Danian planktonic foraminifera. The first lineage appeared about $5 \mathrm{kyr}$ after the $\mathrm{K} / \mathrm{Pg}$ boundary catastrophic mass extinction and is attributed to the parvularugoglobigerinids (Parvularugoglobigerina and Palaeoglobigerina). The second lineage appeared approximately 35 kyr after the K/Pg boundary event and is assigned to Trochoguembelitria Arenillas, ARZ \& NáñEZ, 2012. Morphological and morphostatistical analyses of Trochoguembelitria discriminate at least four species, two of them usually assigned to parvularugoglobigerinids: $T$. alabamensis (Liu \& Olsson, 1992) and T. extensa (Blow, 1979); and two new species: T. liuae sp. nov. and T. olssoni sp. nov.
\end{abstract}

Keywords: planktonic foraminifera, taxonomy, morphostatistics, Paleocene, Tunisia

1. Introduction

2. Material and methods

3. Biostratigraphy and Biochronology

4. Morphology, biometry and morphostatistical analysis

5. Descriptive morphology and results of morphostatistical analysis

\section{Introduction}

After the catastrophic mass extinction of the planktonic foraminifera at the Cretaceous/Paleogene (K/ Pg) boundary, an evolutionary radiation of new planktonic foraminifera species has been widely documented (Luterbacher \& Premoli Silva 1964, Smit 1982, BRINKHUIS \& ZACHARIASSE 1988, CANUDO et al. 1991, D'Hondt 1991, Olsson et al. 1996,

\section{Contents}

6. Discussion .

7. Systematic palaeontology

Acknowledgements

References

Explanation of the paltes

Molina et al. 1998). This evolutionary radiation occurred in two pulses: the first one at approximately 5-20 kyr after the K/Pg boundary extinction event, and the second one at approximately 35-80 kyr (ARENILlas et al. 2000a, b, 2010, 2012). Minute trochospiral species of Palaeoglobigerina Arenillas, Arz \& NÁÑEZ, 2007, and Parvularugoglobigerina HoFKER, 1978, both usually included in Parvularugoglobi-

\footnotetext{
Authors' addresses:

Ignacio Arenillas and José Antonio Arz, Departamento de Ciencias de la Tierra, and Instituto Universitario de Investigación en Ciencias Ambientales de Aragón (IUCA), Universidad de Zaragoza, E-50009Zaragoza, Spain, e-mail: ias@unizar.es, josearz@ unizar.es

Carolina Náñez, Servicio Geológico Minero Argentino and CONICET, Benjamín Lavaisse 1194, C1107BJD Buenos Aires, Argentina, e-mail: carolina.nanez@yahoo.com
} 
gerina (e.g., Olsson et al. 1999), as well as biserial species of Woodringina LoeBlich \& TAPPAN, 1957, evolved during the earlier evolutionary pulse. In the second pulse, more modern genera evolved, including Chiloguembelina Loeblich \& TAPpan, 1956, Eoglobigerina Morozova, 1959, Parasubbotina Olsson, Hemleben, Berggren \& Liu, 1992, Globanomalina Haque, 1956, Praemurica Olsson, Hemleben, Berggren \& LiU, 1992, and Trochoguembelitria ARENILlas, Arz \& NÁÑEz, 2012. Finally, other significant genera of the early Danian, such as Globoconusa Khalilov, 1956, and Subbotina Brotzen \& PoZARYSKA, 1961, evolved later around 150-250 kyr after the K/Pg boundary event.

Although microperforate trochospiral species of the lowermost Danian have usually been included in Parvularugoglobigerina, a detailed analysis of Tunisian sections suggested that two lineages of quasi-homeomorph species but of a different wall texture can be recognized. The first lineage exhibits a smooth wall texture with mural pores (e.g., SMIT 1982, BRINKHUIS \& ZaCHARIASSE 1988, Li \& RADFORD 1991, Li et al. 1995) and evolved during the first evolutionary pulse. Its species were attributed by Arenillas et al. (2012) to the parvularugoglobigerinids (Parvularugoglobigerina and Palaeoglobigerina), such as Parvularugoglobigerina eugubina (LUTERBACHER \& PREMOLI SILVA, 1964) and Palaeoglobigerina alticonusa (LI, McGowran \& Boersma, 1995).

The second lineage has a pustulate to rugose wall texture. The rugosity is caused by coalescing poremounds and/or blunt pustules, generating small, not aligned rugae or ridges. Pustules and rugosities are imperforate or with decentred or peripherally associated pores. Scattered irregularly shaped pore-mounds can also be observed. This type of wall texture evolved during the second Danian evolutionary radiation. Wall texture and biostratigraphic data suggest that this is a lineage different from the parvularugoglobigerinids, and both probably derived independently from different ancestors. This second lineage was assigned to a new genus, Trochoguembelitria Arenillas, Arz \& NÁÑEZ, 2012, with Guembelitria? alabamensis LIU \& Olsson, 1992, as the type-species. However, detailed qualitative and morphostatistical studies of the morphological variability of Trochoguembelitria remained to be performed. In the present study, we statistically analyze new biometric data of Trochoguembelitria and its phenotypic variability. This enables us to discriminate species within Trochoguembelitria, re-assess its phylogenetic relationships with other early Danian planktonic foraminiferal lineages, and analyze the biostratigraphic implications of these findings.

\section{Material and Methods}

Samples for this study were selected from the lower Danian of the El Kef section, Tunisia, the Global boundary Stratotype Section and Point (GSSP) for the base of the Danian Stage (Molina et al. 2006). The lowermost Danian begins with a $50 \mathrm{~cm}$-thick black clay, overlain by $50 \mathrm{~cm}$-thick dark grey clay (Text-fig. 1). This $100 \mathrm{~cm}$-thick dark clay is informally known as the "K/T Boundary Clay" or K/Pg boundary Clay, and its base is characterized by a $1-3 \mathrm{~mm}$ thick rust-coloured ferruginous layer, usually referred to as the "K/T airfall layer". The K/Pg boundary was formally defined at the base of this clay, i.e., at the base of the airfall layer, which contains impact evidence, such as high concentration of iridium, shocked quartz and microspherules. It coincides with the catastrophic mass extinction of the planktonic foraminifera (SMIT 1990, 1999. Arenillas et al. 2000a, b, Molina et al. 2009). At El Kef, the "K/T Boundary Clay" is overlain by a $1 \mathrm{~m}$-thick grey, clay-rich shale, followed by $>$ $10 \mathrm{~m}$-thick white to grey clayey marls. The original proposal and the revision of this GSSP including detailed stratigraphical and micropalaeontological descriptions can be found in Molina et al. (2006).

Eighty-four Trochoguembelitria specimens from lower Danian El Kef samples KF18.50, KF20.50 and KF24.80 (see Text-fig. 1), respectively 6.5, 8.5 and $12.8 \mathrm{~m}$ above the $\mathrm{K} / \mathrm{Pg}$ boundary, were randomly chosen for the morphostatistical analysis. All studied rock samples were disaggregated in water with diluted $\mathrm{H}_{2} \mathrm{O}_{2}$, washed through a $63 \mu \mathrm{m}$ sieve and oven-dried at $50^{\circ} \mathrm{C}$. Specimens were picked from the residues and selected for scanning electron microscopy using JEOL JSM 6400 SEM and Zeiss MERLIN FE-SEM at the Microscopy Service of the Universidad de Zaragoza (Spain). Figured specimens are deposited in the $\mathrm{Mu}-$ seo de Ciencias Naturales de la Universidad de Zaragoza (Gobierno de Aragón, Spain). The preservation of the planktonic foraminifera is good (excellent at some samples), although corroded and recrystallized surfaces can be observed in many specimens. No evidence of selective dissolution affecting only cancellate or rugose species has been identified either in El Kef or other Tethyan sections (SMIT 1982, BRINkHUIS \& Zachariasse 1988, Arenillas et al. 2000a, b). 
Molina et al. $(2006,2009)$ demonstrated that El Kef is - based on its continuity, exposure, completeness, and abundance and preservation of foraminifera - the best section worldwide for analyzing the taxonomy and evolution of the lowermost Danian planktonic foraminifera.

\section{Biostratigraphy and Biochronology}

The biozonation is based on that proposed by ARENILLAS et al. (2004) for the lower Danian (Textfig. 1). It includes the three classical lower Danian biozones, i.e., the Guembelitria cretacea, Parvularugoglobigerina eugubina and Parasubbotina pseudobulloides Zones (SMit 1982, Toumarkine \& LuterBACHER 1985, SMIT \& Romein 1985), and divides each of these biozones into two subzones: the Hedbergella holmdelensis and Parvularugoglobigerina longiapertura Subzones in the G. cretacea Zone, the Parvularugoglobigerina sabina and Eoglobigerina simplicissima Subzones in the Pv. eugubina Zone, and the Eoglobigerina trivialis and Subbotina triloculinoides Subzones in the $P$. pseudobulloides Zone. The lower boundaries of these subzones and their calibration to the numerical time scale according to Arenillas et al. (2004) are the following: (1) highest stratigraphi- cal occurrence (HSO) of Plummerita hantkeninoides and/or Abathomphalus mayaroensis for the base of the $H$. holmdelensis Subzone (coinciding with the K/Pg boundary, 66.0 Ma according to GRADSTEIN et al. 2012), (2) lowest stratigraphical occurrence (LSO) of $P v$. longiapertura for the base of the homonymous subzone (about $6 \mathrm{kyr}$ after the K/Pg boundary), (3) LSO of Pv. eugubina for the base of the Pv. sabina Subzone (about $18 \mathrm{kyr}$ after the K/Pg boundary), (4) LSO of E. simplicissima for the base of the homonymous subzone (about $35 \mathrm{kyr}$ after the $\mathrm{K} / \mathrm{Pg}$ boundary), (5) LSO of P. pseudobulloides for the base of the E. trivialis Subzone (about $55 \mathrm{kyr}$ after the $\mathrm{K} / \mathrm{Pg}$ boundary) and (6) LSO of $S$. triloculinoides for the base of the homonymous subzone (about $220 \mathrm{kyr}$ after the $\mathrm{K} / \mathrm{Pg}$ boundary). This planktonic foraminiferal succession is recorded in complete and continuous sections in Tunisia, Spain and southeastern Mexico (Arenillas et al. 2004, 2006).

In Text-fig. 1, a correlation with the biozonation of BERGGREN \& PEARSON (2005) is made assuming that the LSO of Pv. longiapertura marks the $\mathrm{P} 0 / \mathrm{P} \alpha$ boundary, the HSO of Pv. eugubina, the Pa/Pla boundary, and the LSO of $S$. triloculinoides, the P1a/ P1b boundary. Nevertheless, this equivalence can be

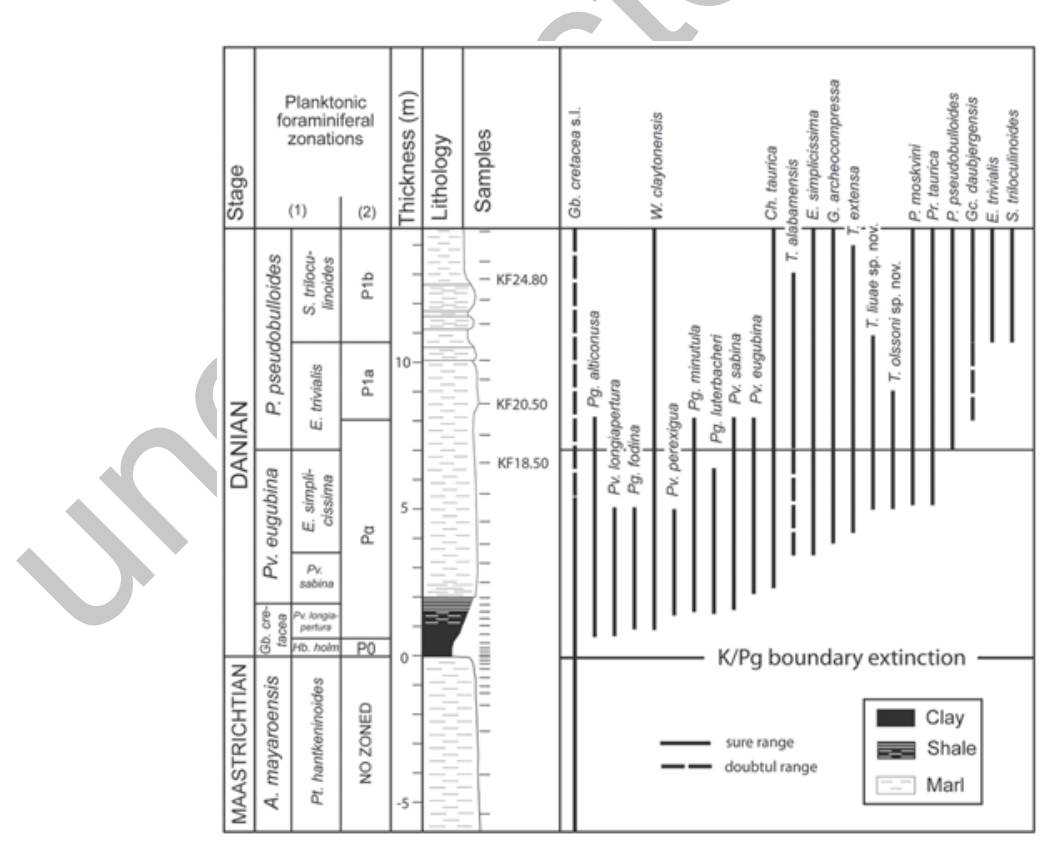

Text-fig. 1. Biostratigraphic ranges of some of the analyzed planktonic foraminifera species: (1) zonation of AreniLLAS et al. (2004), and (2) zonation of Berggren \& PeArson (2005). 
compromised by the varying taxonomic conceptions of Pv. eugubina. The Berggren \& PEARson (2005) biozonation is based on the taxonomy of OLSSON et al. (1999), who amended the genus Parvularugoglobigerina to include specimens with both smooth and pore-mound wall textures and regarded $P v$. longiapertura as a junior synonym of $P v$. eugubina. However, Parvularugoglobigerina had usually been interpreted as having a smooth wall texture (SMIT 1982, BRINKHUIS \& ZACHARIASSE 1988, LI \& RADFORD 1991, Li et al. 1995, Arenillas \& Arz 2000). The top of Zone P $\alpha$ of Berggren \& Pearson (2005) may be higher than illustrated in Text-fig. 1 , as it would encompass species with pustulate to rugose wall texture, here included in Trochoguembelitria.

Another factor that may influence the correlation between biozones is the presence of hiatuses in those reference sections on which the biozonations have been based. For example, hiatuses affecting at least the $H$. holmdelensis Subzone and the "K/T Boundary Clay" are frequent in most of the $\mathrm{K} / \mathrm{Pg}$ boundary sections in the region of the Gulf of Mexico (ARENILlas et al. 2006, Molina et al. 2009). In Tethyan sections, the $H$. holmdelensis Subzone spans much of the "K/T Boundary Clay", and is characterized exclusively by the presence of Guembelitria and other possible Cretaceous survivors of the $\mathrm{K} / \mathrm{Pg}$ boundary extinction event. According to its original definition (SMIT 1982, SMIT \& Romein 1985), the Zone P0 contains no planktonic foraminiferal species originating in the early Danian. The occurrence of rugose Trochoguembelitria, pitted Globanomalina and cancellate Eoglobigerina, Parasubbotina and Praemurica just above the $\mathrm{K} / \mathrm{Pg}$ boundary is indicative that the section has a hiatus corresponding to the lowermost Danian, probably the H. holmdelensis, Pv. longiapertura and Pv. sabina Subzones. Consequently, the H. holmdelensis Subzone of Arenillas et al. (2004) can be correlated with the Zone P0 of SMIT (1982) and SMIT \& RomeIN (1985), but probably not with the Zone P0 of OLSson et al. (1999), since they record representatives of the genera Globanomalina, Eoglobigerina and Praemurica.

At El Kef, the LSO of Trochoguembelitria is in the transition between the Pv. sabina and E. simplicissima Subzones, i.e. in the middle part of Zone $\mathrm{P} \alpha$ (Textfig. 1). The first Trochoguembelitria species to appear seems to be $T$. alabamensis, about $35 \mathrm{kyr}$ after the $\mathrm{K} /$ Pg boundary event according to the biochronology by Arenillas et al. (2004). This datum coincides ap- proximately with the LSOs of Eoglobigerina and Globanomalina and the beginning of the second evolutionary radiation after the mass extinction at the $\mathrm{K} /$ Pg boundary. At El Kef, the HSO of Trochoguembelitria is in the lower part of the S. triloculinoides Subzone, approximately $300 \mathrm{kyr}$ after the K/Pg boundary. This datum coincides with the HSO of Pv. eugubina (top of Zone P $\alpha$ ) as suggested by BERGgren \& PEARsoN (2005), approximately $280 \mathrm{kyr}$ after the $\mathrm{K} / \mathrm{Pg}$ boundary according to the biochronological calibrations proposed by GradsTeIn et al. (2012). Although it should be further clarified, this datum supports the hypothesis that the top of the Zone $\mathrm{P} \alpha$ of Berggren \& PEARson (2005) is based on the HSO of Trochoguembelitria species such as T. liuae sp. nov. and T. olssoni sp. nov., which is in agreement with the wider taxonomic conception of $P v$. eugubina of these authors. The highest record of smooth-walled $P v$. eugubina occurs in the lower part of the E. trivialis Subzone at El Kef and other Tethyan, Gulf of Mexico and Caribbean sections, i.e. approximately $60 \mathrm{kyr}$ after the $\mathrm{K} / \mathrm{Pg}$ boundary.

\section{Morphology, biometry and morphostatisti- cal analysis}

As mentioned above, Trochoguembelitria species show morphological similarities with some species of Palaeoglobigerina and Parvularugoglobigerina, to which they have been attributed in previous studies (see references in Arenillas et al. 2012). For comparison, Plate 1 illustrates the most important Palaeoglobigerina and Parvularugoglobigerina species according to Arenillas et al. $(2007,2012)$, and Plate 2 the Trochoguembelitria species discussed in the present paper. In order to distinguish the Trochoguembelitria species, we have mainly used the following qualitative and quantitative morphological characters (see Textfig. 2):

\section{1) Aperture position and shape}

We have followed the traditional terminologies of LOEBLICH \& TAPPAN (1987) to describe the position and shape of the aperture (Text-fig. 2). According to these authors, there are three types of apertural position in spiral tests: (1) umbilical (or intraumbilical), if the aperture opens completely into the umbilicus; (2) umbilical-extraumbilical (or extraumbilical-umbilical), if it extends from the umbilicus towards the periphery of the test; and (3) extraumbilical, if it is not connected with the umbilicus; the latter includes the 
peripheral or equatorial position, if it opens completely in the periphery. All of them are interiomarginal, i.e. with the aperture located at the basal margin of the final chamber (LOEBLICH \& TAPPAN 1987). The umbilical position is typical of high trochospiral and triserial tests, the umbilical-extraumbilical position of low trochospiral tests, and the peripheral or equatorial position of planispiral tests.

Since all planktonic foraminifera discussed in this paper are trochospiral (Plates 1-4), we have used a more precise terminology for the location of the aperture based mainly on Li (1987) and BoudagheRFADEL (2012). We have subdivided the types of apertural position in trochospiral tests into two subtypes each (Text-fig. 2A): intraumbilical and anterio-intraumbilical for umbilical apertures, and intra-extraumbilical and umbilical-peripheral for umbilicalextraumbilical apertures. Their definition is as follow: (1a) intraumbilical, if the aperture is centred in the umbilicus; (1b) anterio-intraumbilical, if the aperture is located in the umbilicus but is slightly asymmetrical and tends to warp towards the periphery; (1c) intraextraumbilical, if the aperture is located in the umbilical area extending towards the periphery but does not reach it; and (1d) umbilical-peripheral, if it extends from the umbilicus up to the periphery.

The apertures of the planktonic foraminifera discussed in this paper have the following morphologies: (a) a semicircular, wide arch, (b) a elongate, wide arch, and (c) a narrow, high arch (like a loop). Trochoguembelitria, usually has wide-arched apertures surrounded by a thin lip, generally being rounded in intraumbilical and anterio-intraumbilical apertures, and marginally elongate in intra-extraumbilical and umbilicalperipheral apertures. In Globoconusa, the aperture is intraumbilical but smaller. In the lowermost Danian,

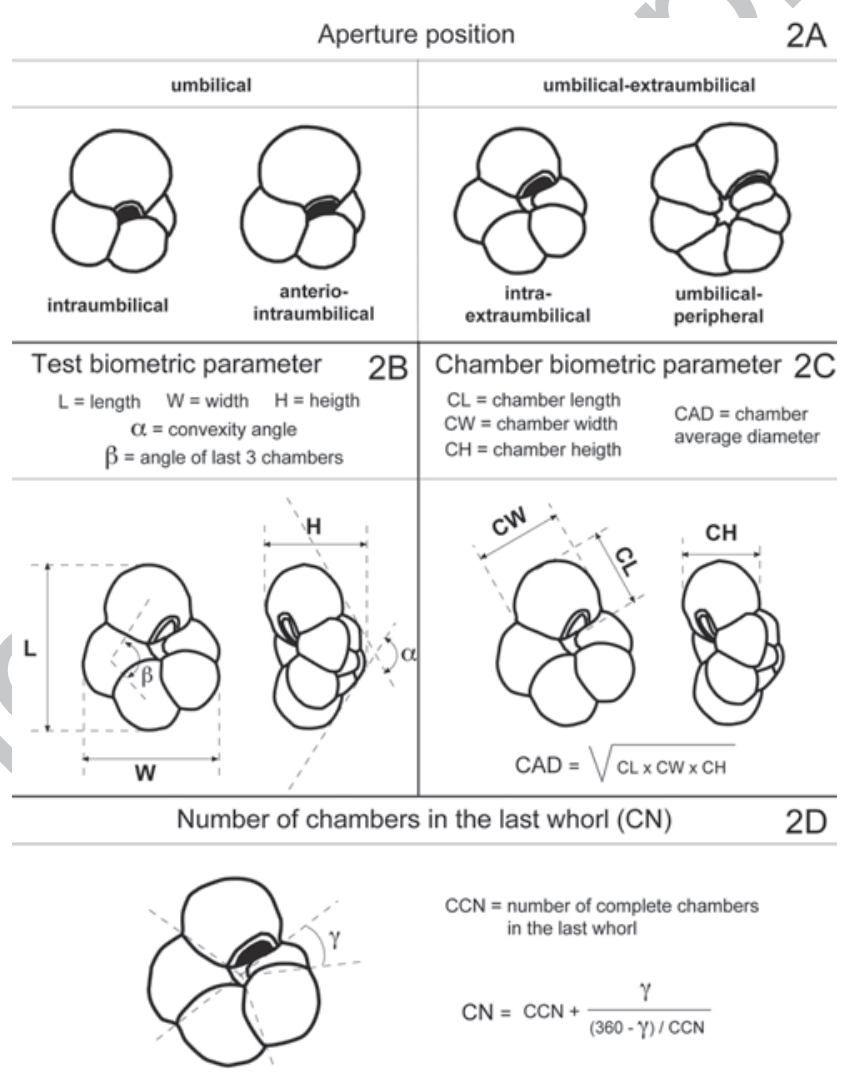

Text-fig. 2. A: Types of aperture position. B: Biometric parameters, abbreviations and descriptive terms used in the morphological analysis of the Trochoguembelitria tests. C: Biometric parameters, abbreviations and descriptive terms used in the morphological analysis of the Trochoguembelitria chambers. 
Table 1. Biometric measurements (in microns) of Trochoguembelitria specimens, and biometric index CAD/H. Arithmetic means in bold type. L, test length; W, test width; $\mathrm{H}$, test height; CAD, chamber average diameter; $\alpha$ : test convexity angle measured in axial view; $\beta$ : angle made by centres of the last three chambers; $\mathrm{CN}$ : number of chambers in the last whorl.

\begin{tabular}{|c|c|c|c|c|c|c|c|c|}
\hline \multicolumn{9}{|c|}{ Trochoguembelitria alabamensis } \\
\hline Specimen & $\mathrm{L}$ & $\mathrm{W}$ & $\mathrm{H}$ & CAD & $\mathrm{a}$ & $\mathbf{b}$ & $\mathrm{CN}$ & $\mathrm{CAD} / \mathrm{H}$ \\
\hline 1 & 112 & 94,9 & 126,2 & 73,1 & 79,8 & 81,7 & 3,7 & 57,9 \\
\hline 2 & 106,7 & 87,2 & 140,1 & 81,1 & 61,3 & 67,3 & 3,3 & 57,9 \\
\hline 3 & 148,6 & 121,3 & 163,5 & 100,5 & 76,9 & 68,1 & 3,3 & 61,5 \\
\hline 4 & 92,5 & 78,4 & 99,9 & 66,3 & 81,3 & 69,3 & 3,0 & 66,4 \\
\hline 5 & 92,9 & 88,9 & 99,8 & 62 & 84,1 & 85,2 & 3,6 & 62,2 \\
\hline 6 & 109,6 & 85,5 & 128,1 & 82 & 75,7 & 81,4 & 3,5 & 64,0 \\
\hline 7 & 99,4 & 83,8 & 104,8 & 67,4 & 92,3 & 86,5 & 3,7 & 64,4 \\
\hline 8 & 108,8 & 91,4 & 123,2 & 76,4 & 78,7 & 77,1 & 3,4 & 62,0 \\
\hline 9 & 126,5 & 108,3 & 143,2 & 88,6 & 74,2 & 70,3 & 3,4 & 61,9 \\
\hline 10 & 110,3 & 93,3 & 127,3 & 80,6 & 80,0 & 73,2 & 3,3 & 63,3 \\
\hline Average & 110,7 & 93,3 & 125,6 & 77,8 & 78,4 & 76,0 & 3,4 & 62,1 \\
\hline \multicolumn{9}{|c|}{ Trochoguembelitria extensa } \\
\hline Specimen & $\mathrm{L}$ & $\mathrm{W}$ & $\mathrm{H}$ & CAD & a & $\mathbf{b}$ & $\mathrm{CN}$ & $\mathrm{CAD} / \mathrm{H}$ \\
\hline 1 & 125,8 & 103,2 & 97,8 & 77,7 & 112,7 & 83,4 & 3,8 & 79,4 \\
\hline 2 & 162,1 & 137,2 & 141,3 & 102,9 & 106,7 & 85,0 & 3,8 & 72,8 \\
\hline 3 & 174,0 & 145,2 & 133,8 & 106,3 & 117,2 & 86,2 & 3,6 & 79,5 \\
\hline 4 & 132,5 & 123,5 & 88,6 & 80,1 & 130,4 & 78,0 & 3,7 & 90,4 \\
\hline 5 & 176,9 & 149,3 & 138,1 & 106,4 & 116,3 & 91,8 & 3,9 & 77,1 \\
\hline 6 & 116,3 & 117,9 & 114,5 & 76,9 & 100,4 & 77,3 & 3,7 & 67,2 \\
\hline 7 & 178,3 & 158,5 & 133,0 & 105,2 & 119,8 & 79,5 & 3,6 & 79,2 \\
\hline 8 & 176,2 & 147,6 & 120,4 & 105,2 & 131,1 & 86,4 & 3,8 & 87,4 \\
\hline 9 & 186,9 & 152,6 & 120,9 & 105,4 & 147,0 & 91,3 & 3,7 & 87,2 \\
\hline 10 & 155,6 & 161,4 & 164,1 & 105,3 & 104,2 & 72,7 & 3,6 & 64,2 \\
\hline 11 & 170,1 & \begin{tabular}{|l|}
139,4 \\
\end{tabular} & 148,9 & 104,3 & 113,3 & 91,4 & 3,8 & 70,1 \\
\hline 12 & 157,3 & 143,6 & 162,3 & 109,2 & 98,3 & 80,1 & 3,7 & 67,3 \\
\hline 13 & 137,3 & 121,8 & 144,6 & 92,3 & 106,0 & 76,0 & 3,0 & 63,9 \\
\hline 14 & 104,3 & 92,5 & 95,4 & 61,0 & 101,4 & 76,2 & 3,8 & 63,9 \\
\hline 15 & 113,8 & 95,0 & 106,2 & 81,0 & 114,8 & 77,2 & 3,3 & 76,2 \\
\hline 16 & 92,3 & 84,1 & 93,5 & 60,1 & 108,4 & 81,0 & 3,5 & 64,2 \\
\hline 17 & 99,7 & 74,9 & 83,0 & 63,1 & 108,8 & 87,1 & 3,3 & 76,1 \\
\hline 18 & 153,3 & 148,6 & 163,7 & 112,0 & 108,2 & 74,4 & 3,8 & 68,4 \\
\hline 19 & 136,4 & 125,2 & 141,3 & 94,3 & 115,5 & 80,7 & 3,9 & 66,8 \\
\hline 20 & 107,0 & 94,5 & 104,2 & 74,2 & 116,8 & 76,6 & 3,6 & 71,2 \\
\hline 21 & 102,2 & 90,9 & 101,6 & 73,4 & 100,0 & 74,8 & 3,5 & 72,2 \\
\hline 22 & 107,6 & 86,7 & 105,4 & 73,5 & 104,3 & 79,7 & 3,1 & 69,8 \\
\hline 23 & 110,4 & 87,6 & 117,8 & 75,8 & 114,8 & 84,4 & 3,5 & 64,3 \\
\hline 24 & 127,4 & 105,5 & 123,5 & 85,8 & 105,9 & 85,0 & 3,7 & 69,5 \\
\hline 25 & 138,5 & 121,2 & 123,2 & 89 & 108,7 & 81,7 & 3,6 & 72,2 \\
\hline 26 & 152,1 & 146,4 & 136,4 & 101,5 & 109,7 & 82,3 & 3,7 & 74,4 \\
\hline 27 & 124,8 & \begin{tabular}{|l|}
107,8 \\
\end{tabular} & 112,4 & 82,6 & 109,2 & 81,9 & 3,5 & \begin{tabular}{|l|}
73,5 \\
\end{tabular} \\
\hline 28 & 141,8 & \begin{tabular}{|l|}
127,4 \\
\end{tabular} & 130,2 & 95 & 105,2 & 78,3 & 3,5 & 73,0 \\
\hline 29 & 135,2 & 115,4 & 116,4 & 88,2 & 112,3 & 83,2 & 3,6 & 75,7 \\
\hline Average & 137,8 & 120,9 & 122,8 & 89,2 & 112,0 & 81,5 & 3,6 & 73,0 \\
\hline
\end{tabular}




\begin{tabular}{|c|c|c|c|c|c|c|c|c|}
\hline \multicolumn{9}{|c|}{ Trochoguembelitria liuae sp. nov. } \\
\hline Specimen & $\mathrm{L}$ & $\mathrm{W}$ & $\mathrm{H}$ & CAD & $\mathbf{a}$ & b & $\mathrm{CN}$ & $\mathrm{CAD} / \mathrm{H}$ \\
\hline 1 & 103,4 & 85,8 & 69,4 & 64,3 & 137,9 & 99,0 & 4,6 & 92,7 \\
\hline 2 & 116,3 & 96,0 & 79,5 & 71,7 & 135,2 & 99,5 & 4,4 & 90,1 \\
\hline 3 & 158,6 & 130,6 & 103,3 & 86,8 & 147,1 & 101,1 & 4,5 & 84,0 \\
\hline 4 & 132,9 & 108,8 & 95,9 & 79,4 & 129,9 & 101,9 & 4,5 & \begin{tabular}{|l|}
82,8 \\
\end{tabular} \\
\hline 5 & 130,4 & 97,4 & 87,7 & 71,7 & 130,7 & 111,1 & 4,4 & 81,7 \\
\hline 6 & 174,3 & 158,0 & 133,8 & 106,9 & 118,7 & 102,3 & 5,3 & 79,9 \\
\hline 7 & 137,5 & 118,0 & 94,0 & 80,3 & 131,3 & 94,2 & 4,1 & 85,5 \\
\hline 8 & 132,2 & 109,8 & 99,9 & 74,4 & 124,2 & 110,3 & 4,8 & 74,5 \\
\hline 9 & 154,6 & 137,7 & 122,8 & 91,5 & 125,8 & 97,2 & 4,5 & 74,5 \\
\hline 10 & 109,3 & 102,3 & 85,5 & 60,8 & 123,7 & 101,9 & 4,7 & 71,1 \\
\hline 11 & 108,4 & 81,9 & 73,1 & 59,1 & 132,2 & 107,2 & 5,0 & 80,9 \\
\hline 12 & 187,2 & 160,7 & 148,1 & 103,6 & 118,2 & 101,7 & 4,5 & 70,0 \\
\hline 13 & 165,4 & 133,5 & 100,3 & 91,6 & 132,1 & 104,2 & 4,7 & 91,3 \\
\hline 14 & 207,0 & 162,2 & 139,7 & 109,2 & 140,1 & 104,5 & 4,7 & 78,1 \\
\hline 15 & 184,3 & 162,1 & 121,2 & 102,0 & 136,7 & 101,0 & 4,5 & 84,2 \\
\hline 16 & 153,3 & 128,7 & 114,0 & 88,2 & 115,6 & 111,6 & 4,7 & 77,3 \\
\hline 17 & 174,2 & 138,4 & 131,2 & 102,3 & 118,8 & 103,2 & 4,4 & 78,0 \\
\hline 18 & 196,9 & 172,1 & 134,6 & 106,4 & 122,6 & 114,2 & 5,0 & 79,0 \\
\hline 19 & 218,8 & 190,0 & 175,9 & 124,4 & 123,6 & 105,1 & 4,7 & 70,7 \\
\hline 20 & 90,3 & 85,9 & 66,5 & 52,9 & 117,9 & 103,9 & 4,8 & 79,6 \\
\hline 21 & 123,2 & 111,3 & 90,5 & 72,6 & 120,0 & 104,3 & 4,8 & 80,2 \\
\hline 22 & 136,3 & 111,4 & 91,4 & 77,0 & 132,1 & 108,8 & 4,7 & 84,2 \\
\hline 23 & 132,0 & 116,1 & \begin{tabular}{|l|}
91,5 \\
\end{tabular} & 77,7 & 144,4 & 109,2 & 4,4 & 85,0 \\
\hline 24 & 192,6 & 161,6 & 139,2 & 117,9 & 138,9 & 96,9 & 4,4 & 84,6 \\
\hline 25 & 132,6 & 123,9 & 100,5 & 71,0 & 134,9 & 101,5 & 4,5 & 70,7 \\
\hline 26 & 93,8 & 86,6 & 69,6 & 55,8 & 131,2 & 92,3 & 4,7 & 80,2 \\
\hline 27 & 150,9 & 128,1 & 106,3 & 86,0 & 122,4 & 108,7 & 4,6 & 80,9 \\
\hline 28 & 140,3 & 123,0 & 108,7 & 86,6 & 124,1 & 90,1 & 4,3 & 79,6 \\
\hline 29 & 146,4 & 124,0 & 103,5 & 83,9 & 131,4 & 104,5 & 4,6 & 81,0 \\
\hline 30 & 131,0 & 114,1 & 94,3 & 75,9 & 127,7 & 104,5 & \begin{tabular}{|l|}
4,7 \\
\end{tabular} & \begin{tabular}{|l|}
80,5 \\
\end{tabular} \\
\hline 31 & 161,4 & 133,6 & 112,7 & 92,8 & 136,1 & 105,4 & 4,5 & 82,3 \\
\hline 32 & 158,9 & 143,7 & 114,6 & 96,0 & 124,6 & 92,6 & 4,3 & 83,8 \\
\hline Average & 148,0 & 126,2 & 106,2 & 85,0 & 129,1 & 102,9 & 4,6 & 80,6 \\
\hline \multicolumn{9}{|c|}{ Trochoguembelitria olssoni sp. nov. } \\
\hline Specimen & $\mathrm{L}$ & $\mathrm{W}$ & $\mathrm{H}$ & CAD & $\mathbf{a}$ & b & $\mathrm{CN}$ & $\overline{\mathrm{CAD} / \mathrm{H}}$ \\
\hline 1 & 139,5 & 115,8 & 85,5 & 71,8 & 164,6 & 123,0 & 5,5 & 83,9 \\
\hline 2 & 210,0 & 171,9 & 132,6 & 106,6 & 151,3 & 121,6 & 5,1 & 80,4 \\
\hline 3 & 172,4 & 150,4 & 110,3 & 89,5 & 158,8 & 130,9 & 5,2 & 81,2 \\
\hline 4 & 143,9 & 114,1 & 89,0 & 83,7 & 167,5 & 117,2 & 5,0 & 94,0 \\
\hline 5 & 139,3 & 115,9 & 84,1 & 75,4 & 158,8 & 118,6 & 4,7 & 89,7 \\
\hline 6 & 208,7 & 187,0 & 134,5 & 100,4 & 146,6 & 127,1 & 5,4 & 74,6 \\
\hline 7 & 146,5 & 122,3 & 89,5 & 75,6 & 151,3 & 126,7 & 5,3 & 84,5 \\
\hline 8 & 113,2 & 93,8 & 85,3 & 70,7 & 128,1 & 126,7 & 4,9 & 82,9 \\
\hline 9 & 124,8 & 97,2 & 77,1 & 67,0 & 144,5 & 125,1 & 5,4 & 86,9 \\
\hline 10 & \begin{tabular}{|l|}
147,9 \\
\end{tabular} & 129,3 & 102,7 & 81,4 & 133,9 & 118,4 & 4,8 & 79,3 \\
\hline 11 & 161,6 & 134,6 & 100,2 & 86,0 & 155,2 & 125,7 & 5,3 & 85,8 \\
\hline 12 & 168,3 & 138,5 & 107,2 & 93,8 & 157,3 & 119,7 & 5,1 & 87,5 \\
\hline 13 & 152,9 & 129,6 & 93,6 & 79,9 & 149,2 & 125,2 & 5,2 & 85,4 \\
\hline Average & 156,1 & 130,8 & 99,4 & 83,2 & 151,3 & 123,5 & 5,1 & 84,3 \\
\hline
\end{tabular}


high-arched, narrow apertures are typical of many species of parvularugoglobigerinids (e.g., Pv. longiapertura). Thin lips are typical of the species considered in this paper, usually slightly projecting above and along the aperture. More modern Danian genera, such as Eoglobigerina, Parasubbotina, Subbotina, Globanomalina or Praemurica, have a thicker lip, usually transformed into a porticus or a tooth.

2) Biometric parameters and indices

The biometric parameters used to delimit species are the following: convexity angle $(\alpha)$ measured in axial view; angle $(\beta)$ made by centres of the last three chambers in umbilical and/or spiral view; maximum diameter or length $(\mathrm{L})$, width $(\mathrm{W})$ and height $(\mathrm{H})$ of the test; and length $(\mathrm{CL})$, width $(\mathrm{CW})$ and height $(\mathrm{CH})$ of the chamber, used to calculate the chamber average diameter $\mathrm{CAD}=(\mathrm{CL} \times \mathrm{CW} \times \mathrm{CH})^{1 / 3}($ see Textfig. 2B, C, and Table 1). In addition, we used the biometric index $\mathrm{CAD} / \mathrm{H}$. The latter and the biometric variable $\alpha$ are measures of test convexity whereas $\beta$, together with the number of chambers $(\mathrm{CN})$, are measures of the morphology of the equatorial outline ( $\mathrm{Ta}$ ble 1). Other biometric indices have been explored as measures of test convexity, such as $\mathrm{L} / \mathrm{H}$ or $\mathrm{CH} / \mathrm{H}$, and outline morphology, such as $\mathrm{W} / \mathrm{L}$, but these have not given consistent results for separating species.

The number of chambers (CN, "Chamber Number") in the last whorl is a character used to distinguish taxa mainly at the species level, but also at the genus level, as is the case with Subbotina and Eoglobigerina. The number of chambers in the last whorl in the lower Danian planktonic foraminifera varies between 3 and 8 , and between 3.5 and 5.5 for Trochoguembelitria. To calculate the number of chambers, we have counted the number of complete chambers in the last whorl, and the percentage of the first chamber of the last whorl visible on the umbilical side. This observable percentage was calculated using the angle $(\gamma)$ between the umbilical centre and the sutures of the chamber, and dividing by the average angle of the other chambers (Text-fig. 2D). The observable percentage was also calculated by measuring the length of the first chamber of the last whorl on the umbilical side divided by the length of the same chamber on the spiral side. The results are similar in both cases, therefor we opted for the first method of calculation (Table 1).

3) Morphostatistical analyses

For morphostatistical analyses, the software used was the program PAST, version 2.17 c, by HAMMER et al.
(2001). The biometric parameters and indices were treated statistically using the following analysis:

i Univariate analyses: Three above-mentioned biometric indices $(\alpha, \beta$ and $\mathrm{CAD} / \mathrm{H})$ and the number of chambers $(\mathrm{CN})$ were analyzed in an univariate manner in order to ascertain whether these biometric variables are useful for discriminating species; the results of the univariate analyses were displayed as histograms of 15 bins (Text-fig. 3). Mixture analysis was applied to each biometric variable in order to identify two or more univariate normal distributions (Gaussian bell-shaped curves) based on a pooled univariate sample; this method is used to identify species and study differences between them; Kernel density estimates were also plotted on histograms.

ii Bivariate analyses: Paired variables were used to make four bivariate analyses: $\mathrm{CN}$ vs. $\alpha, \beta$ vs. $\alpha, \mathrm{CN}$ vs. $\beta$, and $\mathrm{CAD} / \mathrm{H}$ vs. $\alpha$. Kernel density estimates allowed us to make smooth maps of point density in XY graphs (Text-fig. 4); the density estimate is based on a Gaussian function, and scales give an estimate of the number of points per area, not a probability density. Given that the variables cover a large range of values, the measures were transformed logarithmically to reduce the wide range to a more manageable size.

iii Multivariate analyses: R-mode cluster analysis and principal component analysis (PCA) were used; the cluster analyses were based on Bray-Curtis index measures among all specimens using the values of the above-mentioned biometric indices/ parameters $(\alpha, \beta, \mathrm{CAD} / \mathrm{H}$ and $\mathrm{CN})$ in order to find groupings that might represent species (Textfig. 5). The PCA was applied to the values of the four biometric indices/parameters (original variables). Such an analysis finds hypothetical variables (components) that account for as much of the variance in the multidimensional data as possible by reducing the data set to two variables (the two most important components) through a routine that finds eigenvalues and eigenvectors (i.e. components) of the variance-covariance correlation matrix. All the original data points were plotted as an $\mathrm{XY}$ graph in the coordinate system given by the two most important components (PC1 and PC2) to enhance visualization of the data sets representing the possible species (Text-fig. 6); 95\%-confidence ellipses, which assume a bivariate normal distribution, and convex hulls, which are the 
smallest convex polygons containing all points, were presented in the scatter diagram. As in the case of bivariate analyses, measures were transformed logarithmically.

\section{Descriptive morphology and results of mor- phostatistical analysis}

The morphological and morphostatistical analyses discriminate at least four species within Trochoguembeli-
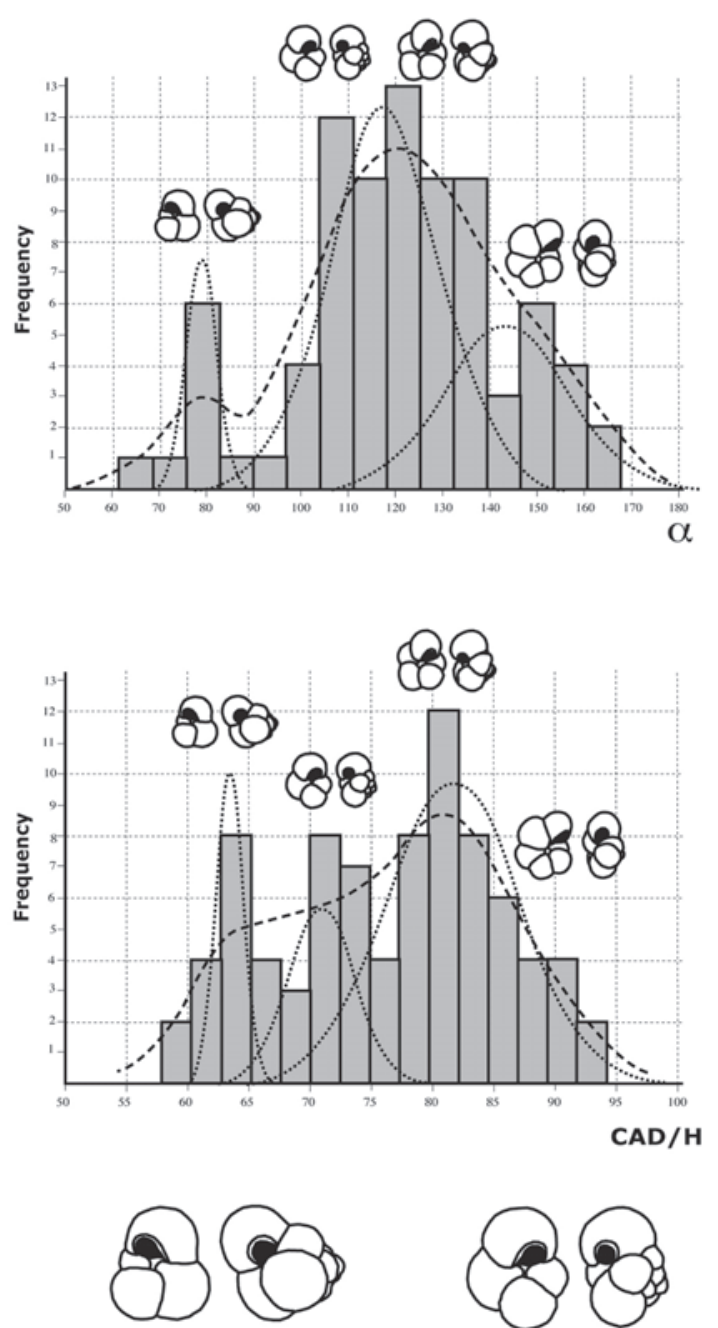

T. alabamensis

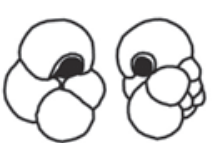

$T$. extensa tria. Whether or not the statistically identified morphogroups are biological species is a question that we do not intend to clarify. Nevertheless, there is no doubt that the four identified species fall within the concept of morphospecies, which is based on overall morphological similarity, and defined as the smallest morphogroup that is consistently and persistently distinct.

Frequency distributions of the univariate analyses (Text-fig. 3), calculated for all measured specimens

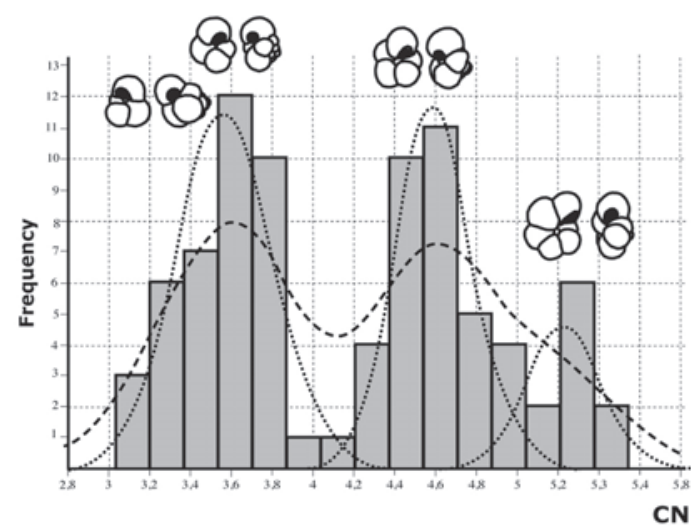

88

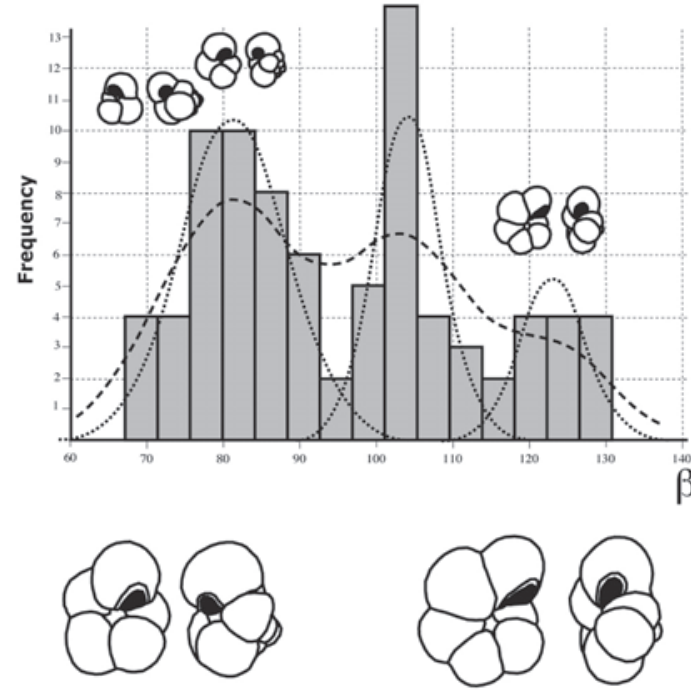

$T$. liuae sp. nov.

T. olssoni sp. nov.

Text-fig. 3. Univariate analyses based on biometric variables $\alpha, \mathrm{CN}, \mathrm{CAD} / \mathrm{H}$ and $\beta$ to delimit the Trochoguembelitria species, displayed as histograms of 15 bins; thick dotted lines are the Kernel density estimations; fine dot lines are univariate normal distributions (Gaussian beel-shaped curves) based on mixture analysis. 
and represented in a plot histogram of 15 bins, suggest four morphogroups of Trochoguembelitria. The biometric variables of test convexity $(\alpha$ and $\mathrm{CAD} / \mathrm{H})$ suggest at least two morphogroups (high-trochospiral, and low- or medium-trochospiral), as suggested by Kernel density estimates. The high-trochospiral morphogroup is assigned to T. alabamensis (LIU \& OLSson, 1992). Histograms and Gaussian bells enable us to recognize three other morphogroups, here assigned to the species T. extensa BLOW (1979), T. liuae sp. nov. and T. olssoni sp. nov. The $\alpha$ variable seems to distinguish two groups, a low-trochospiral group, which can be assigned to T. olssoni sp. nov., and a medium-trochospiral group, which can be assigned to either T. extensa or T. liuae sp. nov. By contrast, the CAD/H variable indicates that both $T$. liuae sp. nov. and $T$. olssoni sp. nov. have a low trochospire, whereas T. extensa is separated by the medium height of its trochospire. In order to separate the latter three morphogroups simultaneously it is more useful to analyze the biometric variables of the equatorial outline $(\beta$ and $\mathrm{CN})$. Univariate Kernel density estimates based on these latter variables indicate at least three morphogroups, which are also observable in the histograms and Gaussian bells. The first morphogroup includes specimens subtriangular or subquadrangular in outline and averaging 3.6 chambers in the last whorl, which can be assigned to either $T$. alabamensis or $T$. extensa. The second morphogroup includes specimens subpentagonal in outline and averaging 4.6 chambers in the last whorl, which are assigned to T. liuae sp. nov. Finally, the third morphogroup includes specimens
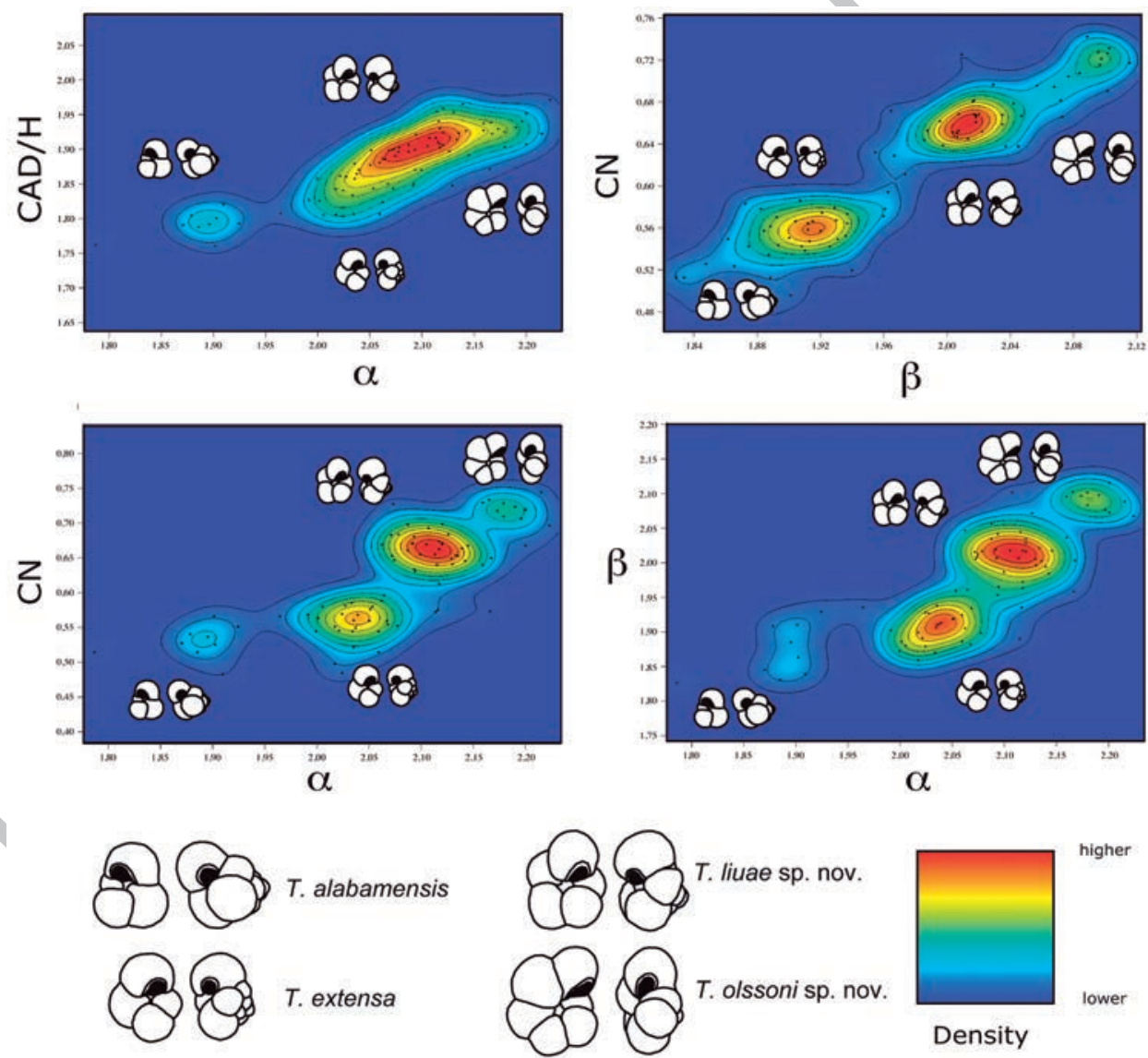

Text-fig. 4. Bivariate analyses based on Kernel density estimations from paired variables (CN vs. $\alpha, \beta$ vs. $\alpha, \mathrm{CN}$ vs. $\beta, \mathrm{CAD} / \mathrm{H}$ vs. $\alpha$ ) and plotted in smooth maps of point density; colour scale with deep red for highest density and dark blue for lowest. 
subcircular in outline and averaging 5.1 chambers in the last whorl, which are assigned to T. olssoni sp. nov.

Bivariate analyses (Text-fig. 4) also strongly suggest that the genus Trochoguembelitria contains four species; these are well observable in the Kernel density maps. If we match the log-transformed variables of test convexity ( $\alpha$ and $\mathrm{CAD} / \mathrm{H})$, two morphogroups can be distinguished, one composed by low- or medium-trochospiral groups (T. extensa, T. liuae sp. nov. and T. olssoni sp. nov.) and the other by the high-trochospiral group (T. alabamensis). As regards the biometric variables of equatorial outline ( $\beta$ and $C N$ ), three morphogroups are well distinguishable in the Kernel density map, which comprise those subtriangular or subquadrangular in outline (T. alabamensis and T. extensa), subpentagonal (T. liuae sp. nov.), and subcircular (T. olssoni sp. nov.). If the biometric variables for different geometrical information are matched, such as $\mathrm{CN}$ vs. $\alpha$ and $\beta$ vs. $\alpha$, four morphogroups emerge clearly, allowing us to discriminate the four above-mentioned species.
Cluster analysis (Text-fig. 5), based on the BrayCurtis similarity index and the log-transformed variables $\alpha, \mathrm{CAD} / \mathrm{H}, \beta$ and $\mathrm{CN}$, produced dendrograms with two primary clusters, one grouping the morphotypes with less than 4 chambers in the last whorl ( $T$. alabamensis and T. extensa) and the other those with more than 4 chambers (T. liuae sp. nov. and T. olssoni sp. nov.). Each of these clusters is further subdivided into two sub-clusters, which are well differentiated by their equatorial outline and test convexity. The first cluster is subdivided in medium-trochospiral and high-trochospiral morphogroups, which are assigned to T. extensa and T. alabamensis respectively. The second cluster is subdivided into subpentagonal specimens with 4-4.5 chambers in the last whorl represented by $T$. liuae sp. nov. and subcircular specimens with more than 4.5 chambers represented by T. olssoni sp. nov. Except for anomalous specimens or intermediate morphotypes, the identified clusters correspond to morphogroups that can be distinguished under the stereomicroscope.

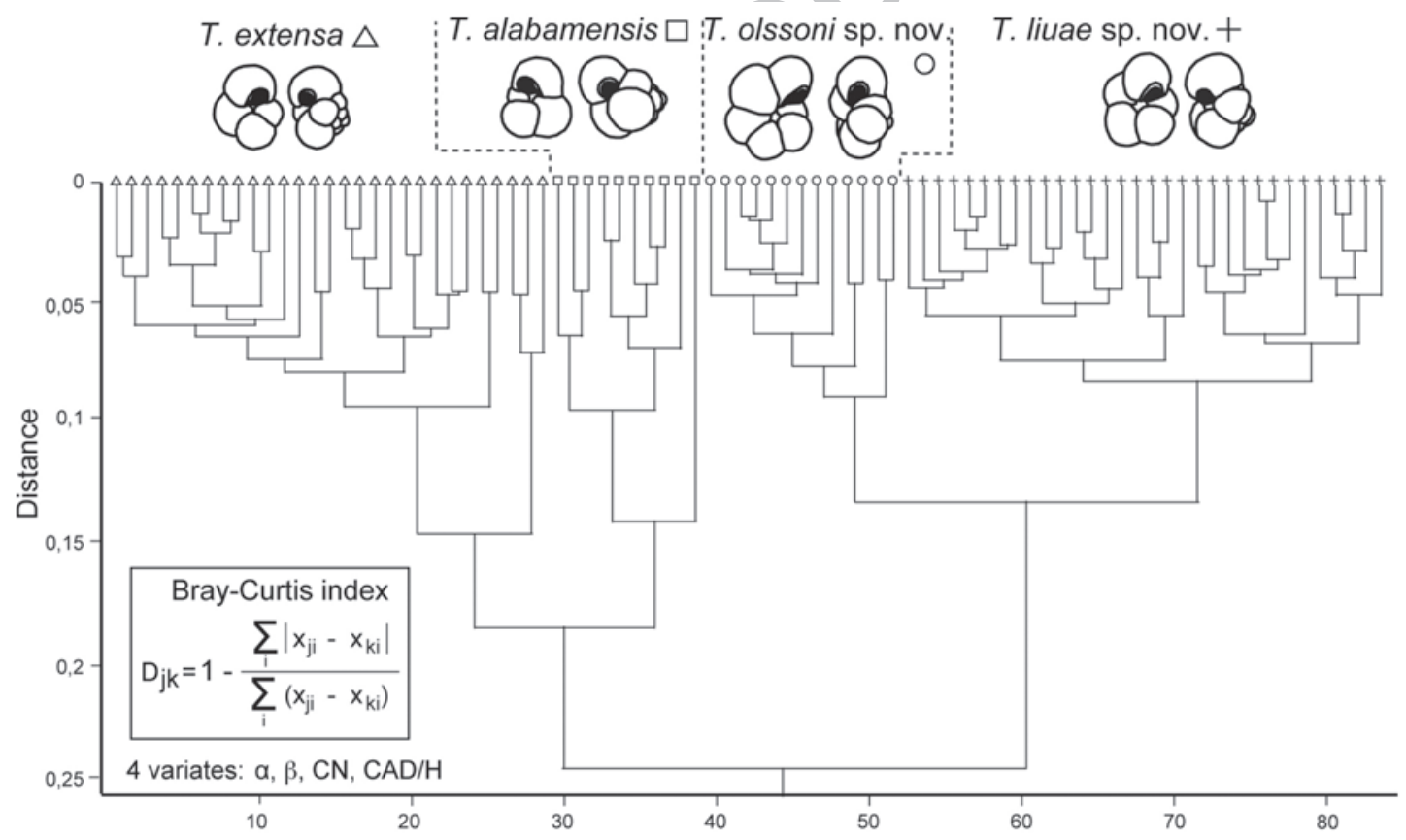

Text-fig. 5. R-mode cluster analysis based on Bray-Curtis index and applied to the values of the biometric variables $(\alpha, \beta, \mathrm{CAD} / \mathrm{H}$ and CN) measured in all Trochoguembelitria specimens photographed by SEM. $D_{i k}=$ Bray-Curtis index value between specimen $j$ and specimen $\mathrm{k} ; \mathrm{x}_{\mathrm{ij}}=$ value of the variable $\mathrm{i}$ (biometric index/parameter $\mathrm{i}$ ) of the specimen $\mathrm{j} ; \mathrm{x}_{\mathrm{ik}}=$ value of the variable $\mathrm{i}$ (biometric index/ parameter i) of the specimen $\mathrm{k}$. 
The principal component analysis (PCA) shows similar results as those of the cluster analysis (Textfig. 6). The principal component PC1 explains $85.8 \%$ of the variance, and the PC2 9.9\%. The PCA scatter diagram, where $\mathrm{X}$ and $\mathrm{Y}$ are the principal components PC1 and PC2, distinguish four sets of points of higher density. We specified four groups of specimens, clustering them subjectively by their gross morphology. They are approximately equivalent to those obtained by the PCA. Except for the intermediate and/ or anomalous specimens, convex hulls and 95\%-confidence ellipses clearly delimit the four species abovementioned. Their main characteristics are easily recognizable under the stereomicroscope.

The position of the aperture in Trochoguembelitria varies from intraumbilical to umbilical-peripheral. The lesser the number of chambers the specimen has in the last whorl, the more centred is the aperture in the umbilicus. In general, $T$. alabamensis has an intraumbilical aperture, T. extensa an anterio-intraumbilical aperture, T. liuae sp. nov. an intra-extraumbilical aperture, and T. olssoni sp. nov. an umbilical-peripheral aperture. The shape of the aperture is usually similar to that of Guembelitria, i.e. large and semicircular but asymmetric due to its elongation toward the periphery and up apertural face. The more peripheral the aperture, the more elongated it is.

\section{Discussion}

Textural, biometric and morphostatistical analyses discriminate four species within the genus Trochoguembelitria: T. alabamensis (LIU \& OLsson, 1992), T. extensa (BLow, 1979), T. liuae sp. nov. and T. olssoni sp. nov. The first two species were originally attributed to Guembelitria? and Eoglobigerina?, respectively. Blow (1979) regarded T. extensa and Globoconusa daubjergensis (BRÖNNIMANN, 1953) as quite closely related on the basis of similarities in wall texture, coiling mode and chamber shape. FORDHAM (1986) suggested the lineage T. extensa-Gc. daubjergensis descended from $G$. cretacea, as also proposed by other authors (e.g., BANG 1969, OLsson 1970, Olsson et al. 1999).

For similar reasons, ARENILLAS et al. (2012) also suggested that Trochoguembelitria is a descendent of the pore-mound walled, triserial Guembelitria and the ancestor of the pustulate-walled, trochospiral Globoconusa. These authors illustrated intermediate specimens between T. cf. fodina, here T. extensa, and $G$ c. daubjergensis from the $E$. trivialis and $S$. triloculinoides

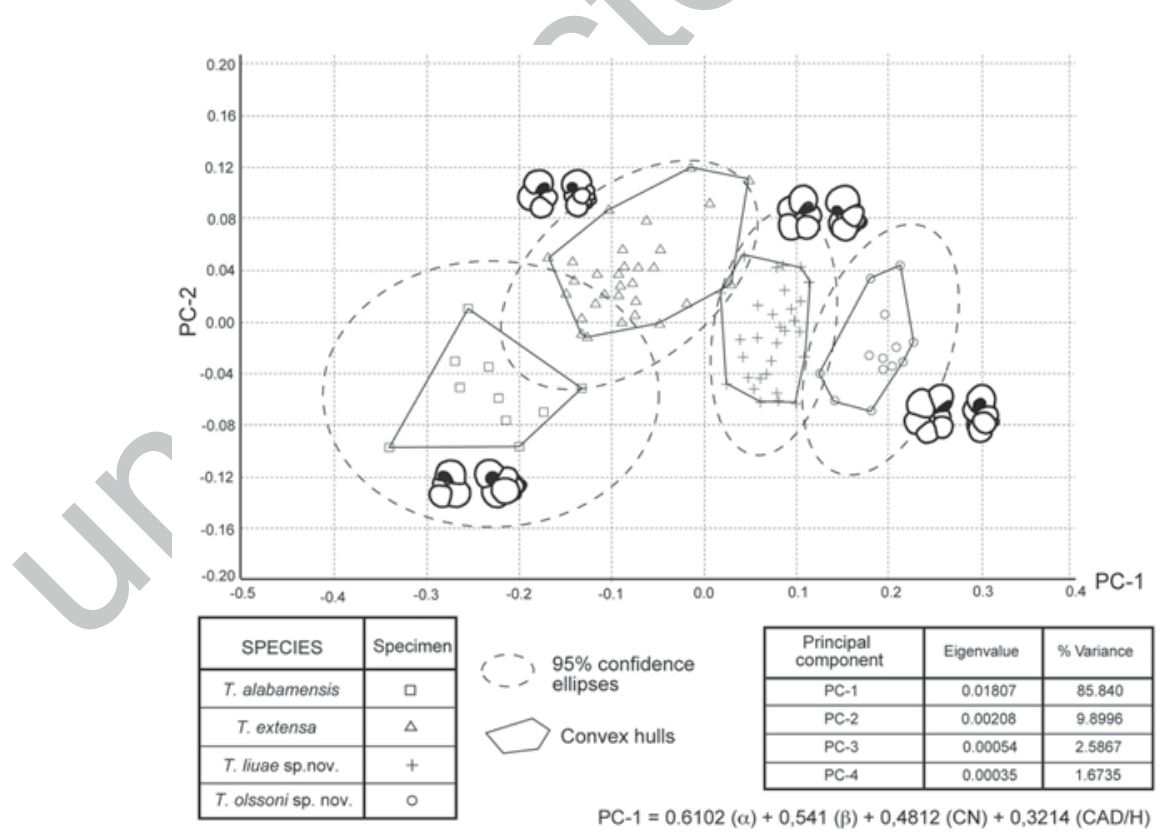

Text-fig. 6. Principal components analysis (PCA), applied to the values of biometric variables $(\alpha, \beta, \mathrm{CAD} / \mathrm{H}$ and $\mathrm{CN})$ in all Trochoguembelitria specimens. 
Subzones, exhibiting a similar gross morphology and a transitional wall texture. The wall texture of these intermediate specimens has pustules sharper than usual in Trochoguembelitria, resembling those of Globoconusa, and suggesting a tendency in Trochoguembelitria to increasingly develop acuminate pustules. At El Kef and other Tethyan sections, the LSO of Gc. daubjergensis s.s. is in the $S$. triloculinoides Subzone (= P1b), but its real LSO might be lower as suggested by data from other sections and cores (e.g., Koutsoukos 2014).

Eoglobigerina? fodina BLow, 1979, here assigned to Palaeoglobigerina, was also included by both BLOw (1979) and FordHAM (1986) in the lineage descending from Guembelitria. However, the holotypes of $P g$. fodina and T. extensa, described from Zone $\mathrm{P} \alpha$ and Zone P1 respectively (BLOw 1979), differ in size and shape. The holotype of Pg. fodina (Plate 1, Fig. 4) is approximately $100 \mu \mathrm{m}$ in length, whereas the holotype of T. extensa (Plate 2, Fig. 5) is approximately 200 $\mu \mathrm{m}$ long. BLow (1979) described a similar wall texture for both species, i.e. finely perforate with very widely and sparsely developed mural pores, and pustules that may be the bases of normal spines. However, the holotypes are recrystallized, so the pustules appear as rather calcite crystals. In addition, there are conspicuous differences in the shape of the aperture. BLOW (1979) noticed that the aperture of Pg. fodina is extremely peculiar and does not match with any other species included either in Eoglobigerina or Globastica BLow, 1979, this latter being a junior synonym of Globoconusa. According to BLOW (1979), it is described as circular, but it has a fairly high arch extending from the umbilicus. It is very similar to the aperture in other species of Parvularugoglobigerina (e.g., Pv. longiapertura) and Palaeoglobigerina (e.g., Pg. alticonusa). The almost rectangular shape of the aperture of the holotype of T. extensa is probably a teratological deformation (Plate 2, Fig. 5). Nevertheless, it may be inferred that it is wider than the aperture of the holotype of Pg. fodina. Given the plasticity of the morphology and location of the aperture in these taxa, OlssoN et al. (1999) considered that such differences are insufficient to maintain T. extensa and Pg. fodina, and other similar species, as separate taxa, and therefore reduced $P g$. fodina to a junior synonym of T. extensa. However, better-preserved specimens from Tunisian sections allowed ArEnillas et al. (2012) not only to observe differences between Pg. fodina and T. extensa in apertural shape and initial spiral arrangement, but also in the wall texture (smooth vs. rugose). BLow (1979) indicated that unlike T. extensa, Pg. fodina has a fairly low trochospire. Given the textural and morphological differences in well-preserved specimens, we retain Pg. fodina in Palaeoglobigerina and assign T. extensa to Trochoguembelitria.

No intergradation between the pustulate to rugose wall texture of Trochoguembelitria and the typically smooth wall texture of parvularugoglobigerinids was observed and consequently both groups are regarded as separate lineages. The occurrence of the minute, smooth-walled parvularugoglobigerinids in the lowermost Danian of Tunisia has been indicated by SMIT (1982), BRINkHUIS \& ZaChaRIASSE (1988), and other authors. BRINKHUIS \& ZACHARIASSE (1988) noted that Parvularugoglobigerina is a very unfortunate generic name for species that have a smooth wall texture and no affinity with Upper Cretaceous Rugoglobigerina BRÖNNIMANN, 1952, and suggested that a more appropriate name would have been Planoconusa as opposed to Globoconusa, in which they included the globular species subsequently assigned to Palaeoglobigerina by Arenillas et al. (2007).

Salaj (1986) defined the genus Postrugoglobigerina in the lowermost Danian of El Kef, composed of the species Pt. hariana and Pt. praedaubjergensis, and based it on characters similar to those later attributed to Trochoguembelitria. Postrugoglobigerina was reported by LOEBLICH \& TAPPAN (1987), and more recently by BOUDAGHER-FADEL (2012) to have a trochospiral test and a microperforate and muricate wall texture. This taxon could have been a good candidate to name the Trochoguembelitria specimens, but the holotypes and type-material of both Postrugoglobigerina species have been lost, are of doubtful application, and must be regarded as nomen dubium non conservandum (see discussion in Arenillas et al. 2012). The taxonomic interpretation of Postrugoglobigerina raises several questions, such as the true nature of its wall texture, the coiling mode of the holotypes of its species, and its biostratigraphic position. This genus should therefore be invalidated, or at least regarded as a junior synonym of Parvularugoglobigerina as proposed by Olsson et al. (1999), since its type-species (Pt. hariana) is probably a junior synonym of $P v$. sabina.

After a detailed re-examination with a SEM-microscope of El Kef samples previously studied by traditional stereomicroscopy, we have noticed that some specimens have to be placed in the genus Trochoguembelitria. They had been previously attributed to quasi- 
homeomorph species belonging to the genera Parvularugoglobigerina, Palaeoglobigerina, Eoglobigerina, Globanomalina and Praemurica (see morphological similarities in Text-fig. 7).

The existence of quasi-homeomorph species and even pseudocryptic (i.e. cryptic species only a posteriori distinguished as morphospecies by wall texture or small morphological details) has been tested in other Tunisian sections (ARENILlas et al. 2010, 2012). Koutsoukos (2014) has also reported new lower Danian species in Globoconusa (Gc. victori) and Praemurica (Pr. nikolasi), indicating that the morphological variability of lower Danian planktonic foraminiferal genera is greater than previously thought (Text-

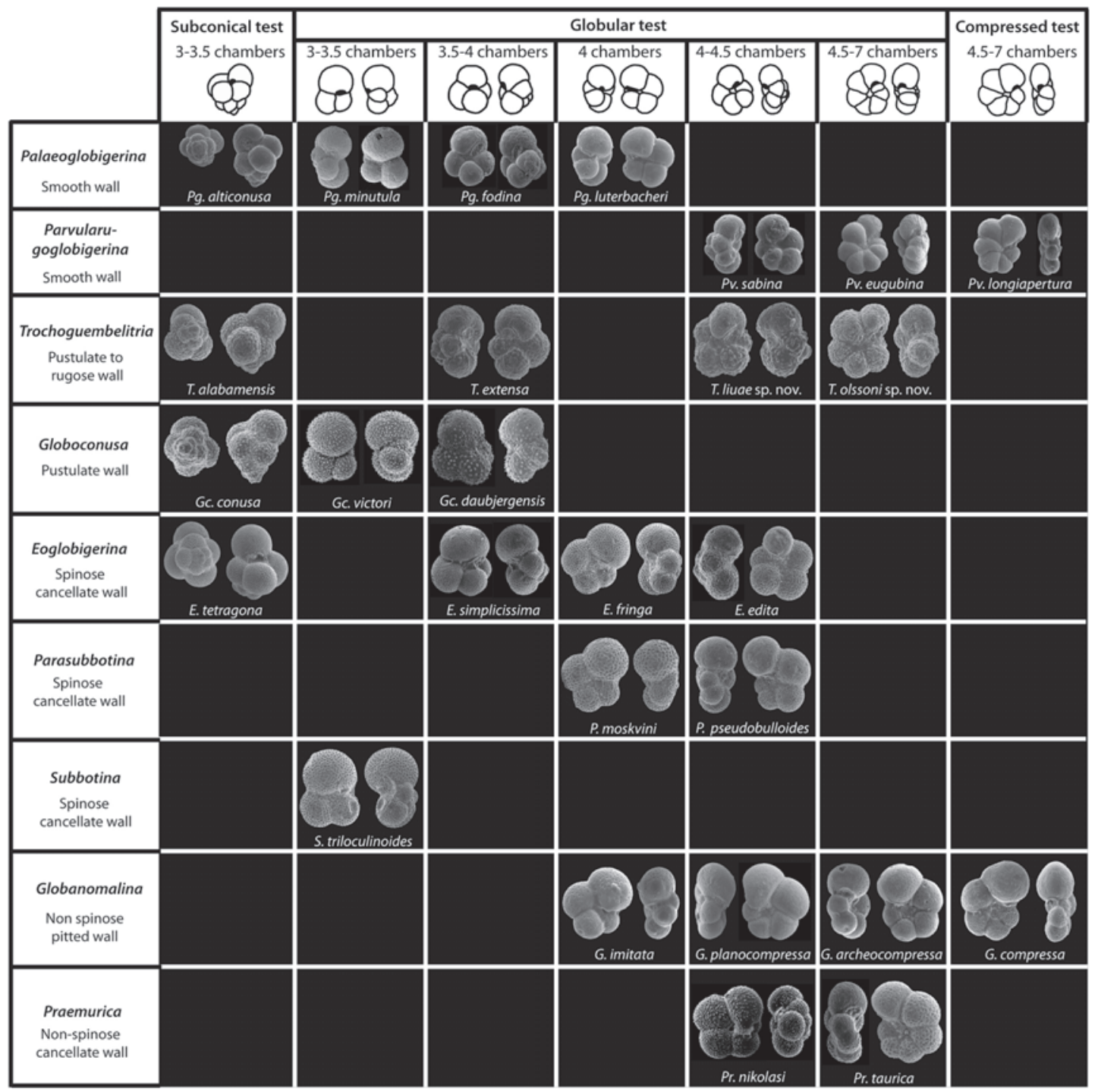

Text-fig. 7. Morphological variability of lower Danian genera Palaeoglobigerina, Parvularugoglobigerina, Trochoguembelitria, Globoconusa, Eoglobigerina, Parasubbotina, Subbotina, Globanomalina and Praemurica, based on number of chambers in the final whorl of species and the shape of the test. Specimens are not to scale. 
fig. 7). The lower Danian planktonic foraminiferal lineages show a broad phenotypic variability, and quasi-homeomorph species belonging to different genera may be rather common. For example, the variations in the number of chambers in the last whorl (3 to 3.5 ; 3.5 to 4 ; 4 ; 4 to 4.5 ; and more than 4.5 ) are commonly used to differentiate species, and even genera, among trochospirally coiled taxa (Text-fig. 7). As a result, species attributed to different genera may have nearly the same gross morphology. The stratigraphical ranges of the pseudocryptic species are therefore difficult to determine accurately because they may be underestimated in routine studies with a stereomicroscope.

Therefore, the biostratigraphic ranges proposed for the Trochoguembelitria species are, mainly in their upper part, still tentative (Text-fig. 1). The rugose wall texture is its main diagnostic character, but is hardly visible under stereomicroscopy or frequently masked by taphonomic and diagenetic processes. Other useful features for recognizing Trochoguembelitria specimens are a frequently protruding proloculus and, to a lesser extent, the shape of their aperture, which comprises a wide, rounded arch with a thin lip, similar to Guembelitria, in some species turning to an elongate, asymmetrical arch, reaching the periphery and extending up the apertural face. However, both these features may display great plasticity in early Danian planktonic foraminifera, and it is difficult to correctly identify these taxa with a stereomicroscope.

\section{Systematic palaeontology}

Order Foraminifera EICHWALD, 1830

Suborder Globigerinina Delage \& Hérouard, 1896

Superfamily Heterohelicoidea CUSHMAN, 1927

Family Guembelitriidae Montanaro-Gallitelli, 1957

Genus Trochoguembelitria Arenillas, Arz \& NÁÑEz, 2012

Type species: Guembelitria? alabamensis LiU \& OLsSON, 1992 Occurrence: Lower Danian, from the E. simplicissima Subzone (middle part of the Pv. engubina Zone) to the middle part of the S. triloculinoides Subzone (middle part of the P. pseudobulloides Zone), i.e., from the middle-upper part of $\mathrm{P} \alpha$ to the middle part of P $1 \mathrm{~b}$ of Berggren \& Pearson (2005). They are common in the transition between Pv. eugubina $(\mathrm{P} \alpha)$ and P. pseudobulloides (P1) Zones.
Composition: Trochoguembelitria alabamensis (LIU \& OLsson, 1992), Trochoguembelitria extensa (Blow, 1979), Trochoguembelitria liuae sp. nov., and Trochoguembelitria olssoni sp. nov.

Description: Trochospiral test, initially triserial or trochospiral. Outline lobate, with incised sutures. Aperture relatively large, umbilical to umbilical-extraumbilical, semicircular to elongated and asymmetrical, with a thin imperforate lip. Wall calcareous hyaline, microperforate, pustulate to rugose consisting of blunt pustules that may coalesce to form small, not aligned rugosities, and scattered pore mounds; pustules and rugosities imperforate or with decentred or peripherally associated pores.

Remarks: Guembelitria s.s. differs from Trochoguembelitria in having a pore-mound wall texture and being triserial throughout. Globoconusa has a pustulate wall texture, with pointed, more sparsely distributed pustules. Parvularuglobigerina and Palaeoglobigerina are smaller and have a smooth wall texture with muralpores (sensu BLOW, 1979, or simple pores according to Loeblich \& Tappan, 1987). Similar specimens were documented by Liu \& OLsson (1992, 1994), and Olsson et al. (1992, 1999), but assigned to Parvularugoglobigerina based on their emendation of this genus. Arenillas et al. (2012) included these specimens with blunt pustules, small rugosities and poremounds in Trochoguembelitria, retaining smoothwalled specimens in Parvularugoglobigerina.

Trochoguembelitria alabamensis (LIU \& OLsson, 1992) (Plate 2, Figs 2-4)

1992 Guembelitria? alabamensis Liu \& Olsson, p. 341, pl. 2, figs $1-7$.

1999 Parvularugoglobigerina alabamensis - OLsson et al., p. 83, part, pl. 65, figs 3, 5-6.

2000 Guembelitria? alabamensis - PApÚ et al., p. 28, pl. 2, figs 9-11.

2007 Guembelitria? alabamensis - Arenillas et al., p. 39, figs 14.1-14.5.

2012 Trochoguembelitria alabamensis - Arenillas et al., p. 133-135, figs 5A, D, 6A, G.

Biostratigraphic occurrence: Lower Danian, from the E. simplicissima Subzone (in the middle part of the Pv. eugubina Zone) to the lower part of the $S$. triloculinoides Subzone (middle part of the $P$. pseudobulloides Zone), i.e., from the middle-upper part of $\mathrm{P} \alpha$ to the lower part of P1b of Berggren \& Pearson (2005).

Description: Trochospiral test, initially triserial, with moderate to very high spire, 9 to 13 spherical chambers in 3 spiral whorls, about 3.5 chambers in the last whorl and low rate of size increase. Outline lobate, subtriangular or subquadrangular, with incised su- 
tures. Aperture umbilical (intraumbilical), semicircular, with a thin imperforate lip. Wall calcareous hyaline, microperforate, pustulate to rugose with blunt pustules and small rugosities, which are imperforate or with decentred or peripherally associated pores, and scattered pore-mounds. Adult size ranges 110-170 $\mu \mathrm{m}$ in height and 90-150 $\mu \mathrm{m}$ in maximum diameter. Remarks: T. extensa differs from $T$. alabamensis in having a lower trochospiral test and an anterio-intraumbilical to intra-extraumbilical, semicircular to slightly asymmetrical and elongated aperture. T. liuae sp. nov. has a lower trochospiral test and a larger number of chambers in the last whorl ( 4 to 5 instead of 3.5 to 4 chambers). Pg. alticonusa is smaller and has a smooth to granular wall texture, and usually a narrow, high arched aperture. LiU \& Olsson (1992) tentatively included $T$. alabamensis in Guembelitria?, and indicated that T. alabamensis differs from Guembelitria cretacea CUSHMAN, 1933, by having a trochospiral test and poreless blunt pustules in the later ontogenetic stage. Olsson et al. (1999) included it in Parvularugoglobigerina after emending this genus.

Trochoguembelitria extensa (BLow, 1979)

(Plate 2, Figs 7-9)

1979

Eoglobigerina? extensa Blow, p. 1220, pl. 69, fig. 7 pl. 74, figs 1-2.

? 1986 Postrugoglobigerina praedaubjergensis SALAJ, p. 54, pl. 3, figs 7-8.

non 1999 Parvularugoglobigerina extensa- OLsson et al., p. $85-86$, pl. 65, figs 7-13.

2012 Trochoguembelitria cf. fodina (BLOW). - ARENILlAS et al., p. 135-137, figs 5B, E-G, 6B-C, 8A.

Biostratigraphic occurrence: Lower Danian, from the middle part of the E. simplicissima Subzone (in the upper part of the $P v$. engubina Zone) up to the middle part of the S. triloculinoides Subzone (middle part of the P. pseudobulloides Zone), i.e., from the upper part of $P \alpha$ to the middle part of P1b of BERGGREN \& PeARSON (2005).

Diagnostic description: Trochospiral test, slightly high spire, 9 to 12 spherical chambers in 3 spiral whorls, 3.5 to 4 chambers in the last whorl, and moderate rate of size increase. Outline lobate, subtriangular or subquadrangular, with incised sutures. Aperture umbilical to umbilical-extraumbilical (anterio-intraumbilical to intra-extraumbilical), semicircular to slightly asymmetrical and elongated, with a thin imperforate lip. Wall calcareous hyaline, microperforate, pustulate to rugose with perforate and/or poreless small rugosities and blunt pustules, and scattered pore-mounds. Adult size range $110-180 \mu \mathrm{m}$ in maximum diameter.

Remarks: T. extensa resembles $P g$. fodina, but the latter is smaller, has a smooth wall texture, and usually a higher arched, narrow aperture. T. alabamensis has a higher trochospiral test (as G. cretacea), and an intraumbilical, semicircular aperture. T. liuae sp. nov. has more chambers in the last whorl ( 4 to 5 instead of 3.5 to 4 chambers). Gc. daubjergensis is larger and has a pustulate wall texture, with sharp pustules, sparsely distributed. T. extensa should not be confused with Parvularugoglobigerina extensa according to OLSSON et al. (1999) since authors grouped into this taxon the trochospiral morphotypes with smooth to granular wall texture classified as Pg. alticonusa, Pg. fodina and Pg. minutula by Li et al. (1995), BLow (1979) and Luterbacher \& Premoli Silva (1964) respectively, and assigned to Palaeoglobigerina by ARENILLAS \& ARZ (2007) and ARENILlas et al. (2007, 2012). T. extensa could be similar to Postrugoglobigerina praedaubjergensis SALAJ, 1986, i.e., high-trochospiral, intraumbilical aperture, and 4 chambers in the last whorl, but the holotype of Pt. praedaubjergensis has been lost and is of doubtful application, so it must be considered nomen dubium non conservandum_(ARENILLAS et al., 2012). In addition, its wall texture and stratigraphical range do not coincide with those proposed herein for T. extensa.

Trochoguembelitria liuae sp. nov.

(Plate 2, Figs 11-12; Plate 3, Fig. 1 (holotype), Fig. 2 (paratype), Fig. 3 (paratype))

?1986 Postrugoglobigerina hariana SALAJ, p. 53, pl. 3, figs $1-2$.

1999 Parvularugoglobigerina engubina - OLsson et al., p. 83-85, part, pl. 66, figs 1-3, 5, 6; pl. 67, figs 13-14.

2012 Trochoguembelitria cf. sabina - Arenillas et al., p. 137, figs 5C, H-J, 6D-F, H, 7B, 8B.

Figured specimens and repository: Holotype MPZ 2014/295 (Plate 3, Fig. 1): maximum diameter or length $=187.2 \mu \mathrm{m}$, width $=160.7 \mu \mathrm{m}$, height $=148.1 \mu \mathrm{m} ;$ Paratype MPZ 2014/296 (Plate 3, Fig. 2): length $=132.2 \mu \mathrm{m}$, width $=108.8 \mu \mathrm{m}$, height $=95.9$ $\mu \mathrm{m}$; Paratype MPZ 2014/297 (Plate 3, Fig. 3): length $=208.7$ $\mu \mathrm{m}$, width $=187.0 \mu \mathrm{m}$, height $=134.5 \mu \mathrm{m}$. Holotype and paratypes are deposited in the Museo de Ciencias Naturales of the Universidad de Zaragoza, Gobierno de Aragón, Spain, with the prefix MPZ.

Etymology: Species dedicated to CHENGJIE LiU, one of the first in identifying these morphotypes.

Type locality: El Haria Formation, El Kef section, Tunisia. 
Type level: $8.5 \mathrm{~m}$ above the Cretaceous/Paleogene boundary of the El Kef section (loc. KF20.50), in the lower part of Subzone P1a, or lower part of Eoglobigerina trivialis Subzone of Parasubbotina pseudobulloides Zone by Arenillas et al. (2004), lower Danian.

Biostratigraphic occurrence: Lower Danian, identified from the middle-upper part of the E. simplicissima Subzone (upper part of the Pv. eugubina Zone) to the E. trivialis Subzone (lower part of the $P$. pseudobulloides Zone), i.e., from the upper part of $\mathrm{P} \alpha$ to the top of Pla of BERGgren \& PEARSON (2005).

Description: Trochospiral test, slightly high spire, 10 to 12 spherical chambers in 3 spiral whorls, 4.5 to 5 chambers in the last whorl, slowly increasing in size. Outline lobate, subpentagonal, with incised sutures. Aperture umbilical to umbilical-extraumbilical (anterio-intraumbilical to intra-extraumbilical), rounded, asymmetrical and elongated, with a thin imperforate lip. Wall calcareous hyaline, microperforate, pustulate to rugose consisting of blunt pustules that may coalesce to form small, not aligned rugosities; pustules and rugosities imperforate or with decentred or peripherally associated pores; scattered pore-mounds. Adult size ranges $120-200 \mu \mathrm{m}$ in maximum diameter. Remarks: T. liuae sp. Nov. strongly resembles $P v$. ostul, but the latter is smaller and has a smooth wall texture. T. extensa differs from T. liuae sp. Nov. in having fewer chambers in the last whorl (3.5 to 4 instead of 4 to 5 chambers) and intraumbilical aperture. T. alabamensis has a higher trochospiral test and lesser number of chambers in the last whorl. T. liuae sp. Nov. also resembles Eoglobigerina edita (SuвBотіNA, 1953) and/or Eoglobigerina praeedita BLow, 1979, which have similar sizes, but these mainly differ in having cancellate wall texture, spines (at least the first one), and often well-developed apertural lips. The morphology of this species could be similar to that described by SALAJ (1986) for Postrugoglobigerina hariana (i.e., low-trochospiral, intraumbilical aperture, and 5 chambers in the last whorl). As Pt. praedaubjergensis, the holotype of this species has been lost and its identification becomes confusing so Pt. hariana should be considered nomen dubium non conservandum; its wall texture and stratigraphical range seem to not coincide with those of T. liuae sp. Nov. Specimens illustrated by OLsson et al. (1999), with pore-mound and/or ostulate wall texture, and five chambers in the last whorl are herein included in T. liuae sp. Nov. They identified these morphotypes as Pv. Eugubina.
Trochoguembelitria olssoni sp. nov.

(Plate 2, Figs 13-14; Plate 4, Fig. 1 (holotype), Fig. 2 (paratype), Fig. 3 (paratype))

1992 Parvularugoglobigerina eugubina - LiU \& OLsson, p. 345 , part, pl. 3 , figs $5-6$.

Figured specimens and repository: Holotype MPZ 2014/298 (Plate 4, Fig. 1): maximum diameter or length $=208.7 \mu \mathrm{m}$, width $=187.0 \mu \mathrm{m}$, height $=134.5 \mu \mathrm{m}$; Paratype MPZ 2014/299 (Plate 4, Fig. 2): length $=139.5 \mu \mathrm{m}$, width $=115.8 \mu \mathrm{m}$, height $=85.5$ $\mu \mathrm{m}$; Paratype MPZ 2014/300 (Plate 4, Fig. 3): length $=139.3$ $\mu \mathrm{m}$, width $=115.9 \mu \mathrm{m}$, height $=84.1 \mu \mathrm{m}$. Holotype and paratypes are deposited in the Museo de Ciencias Naturales of the Universidad de Zaragoza, Gobierno de Aragón, Spain, with the prefix MPZ.

Etymology: Species dedicated to Richard K. Olsson for his work on Danian planktonic foraminifera.

Type locality: El Haria Formation, El Kef section, Tunisia.

Type level: $6.5 \mathrm{~m}$ above the Cretaceous/Paleogene boundary of the El Kef section (loc. KF18.50), in the upper part of Zone $\mathrm{P} \alpha$, or upper part of Eoglobigerina simplicissima Subzone of Parvularugoglobigerina eugubina Zone by Arenillas et al. (2004), lower Danian.

Biostratigraphic occurrence: Lower Danian, identified from the middle-upper part of the E. simplicissima Subzone (upper part of the Pv. eugubina Zone) to the lower part of the E. trivialis Subzone (lower part of the P. pseudobulloides Zone), i.e., from the upper part of $\mathrm{P} \alpha$ to the lower part of P1a of BERGgREN \& PEAR$\operatorname{SON}(2005)$.

Description: Low trochospiral test, 10 to 12 spherical chambers in 3 spiral whorls, 5 to 5.5 chambers in the last whorl, increasing slowly in size. Outline lobate, subcircular, with incised sutures. Aperture umbilicalextraumbilical (intra-extraumbilical to umbilical-peripheral), rounded, asymmetrical and elongated, with a thin imperforate lip. Wall calcareous hyaline, microperforate, pustulate to rugose consisting of blunt pustules that may coalesce to form small, not aligned rugosities; pustules and rugosities imperforate or with decentred or peripherally associated pores; scattered pore-mounds. Adult size ranges $120-210 \mu \mathrm{m}$ in maximum diameter.

Remarks: Similar specimens to T. olssoni sp. nov. were already documented by Liu \& Olsson (1992), but identified as Pv. eugubina. T. olssoni sp. nov. resembles Pv. eugubina, but the latter is smaller and has a smooth wall texture.

\section{Acknowledgements}

We thank the reviewer Hanspeter Luterbacher for his thoughtful and useful comments. This research was funded by the Spanish Ministerio de Ciencia e Innovación projects CGL2011-23077 and CGL2011-22912 (both cofinanced by the European Re- 
gional Development Fund), by the Aragonian Departamento de Educación y Ciencia (DGA group E05), and by the Consejo Nacional de Investigaciones Científicas y Técnicas (Argentina), projects PIP 0820 and PIP 0281. Authors would like to acknowl edge the use of the Servicio General de Apoyo a la InvestigaciónSAI, Universidad de Zaragoza. The authors are grateful to Rupert Glasgow for improvement of the English text.

\section{References}

Arenillas, I. \& Arz, J.A. (2000): Parvularugoglobigerina eu gubina type-sample at Ceselli (Italy): planktic foraminiferal assemblage and lowermost Danian biostratigraphic implications. - Riv. Ital. Paleontol. S. 106 (3): 379-390.

Arenillas, I. \& Arz, J.A. (2007): Análisis morfoestadístico del género Palaeoglobigerina (Foraminifera, Globigerinida) del Paleoceno basal, y descripción de una nueva especie. - Rev. Esp. Micropaleontol. 39 (1-2): 1-28.

Arenillas, I. \& Arz, J.A. (2013a): Origin and evolution of the planktic foraminiferal Family Eoglobigerinidae Blow (1979) in the early Danian (Paleocene). - Rev. Mex. Cienc. Geol. 30 (1): 159-177.

Arenillas, I. \& ArZ, J.A. (2013b): New evidence on the origin of nonspinose pitted-cancellate species of the early Danian planktonic foraminifera. - Geol. Carpathica 64 (3): 237 251.

Arenillas, I., Arz, J.A., Molina, E. \& Dupuis, C. (2000a) An independent test of planktic foraminiferal turnover across the Cretaceous/Paleogene (K/P) boundary at El Kef, Tunisia: Catastrophic mass extinction and possible survivorship. - Micropaleontology 46 (1): 31-49.

Arenillas, I., Arz, J.A., Molina, E. \& Dupuis, C. (2000b): The Cretaceous/Paleogene (K/P) boundary at Ain Settara, Tunisia: sudden catastrophic mass extinction in planktic foraminifera. - J. Foramin. Res. 30 (3): 202-218.

Arenillas, I., Arz, J.A. \& Molina, E. (2004): A new highresolution planktic foraminiferal zonation and subzonation for the lower Danian. - Lethaia 37: 79-95.

Arenillas, I., Arz, J.A., Grajales-Nishimura, J.M., Murillo-Muñetón, G., Alvarez, W., CamargoZanoguera, A., Molina, E. \& Rosales-Domínguez, C. (2006): Chicxulub impact event is Cretaceous/Paleogene boundary in age: new micropaleontological evidence. - Earth Planet. Sci. Lett. 249: 241-257.

Arenillas, I., Arz, J.A. \& NÁÑez, C. (2007): Morfología, Biometría y Taxonomía de foraminíferos planctónicos del Daniense basal: Palaeoglobigerina n. gen. - Rev. Esp. Paleontol. 22 (1): 21-62.

Arenillas, I., ArZ, J.A. \& NáñeZ, C. (2010): Diversidad y evolución de la textura de la pared en guembelítridos (foraminíferos planctónicos) en el tránsito CretácicoPaleógeno. - Rev. Esp. Paleontol. 25 (2): 87-105.

Arenillas, I., ArZ, J.A. \& NÁÑEZ, C. (2012): Smooth and rugose wall textures in earliest Danian trochospiral planktic foraminifera from Tunisia. - Neues Jahrb. Geol. Palaeontol. Abh. 266 (2): 123-142.
Arz, J.A., Arenillas, I. \& NÁÑEZ, C. (2010): Morphostatistical analysis of Maastrichtian populations of Guembelitria from El Kef, Tunisia. - J. Foramin. Res. 40 (2): 148-164.

BANG, I. (1969): Planktonic foraminifera and biostratigraphy of the type Danian. - In: Brönnimann, P. \& Renz, H.H. (eds): Proceedings of the I International Conference on Planktonic Microfossils 1: 17-25.

Berggren, W.A. \& Pearson, P.N. (2005): A revised tropical to subtropical Paleogene planktonic foraminiferal zonation. - J. Foramin. Res. 35: 279-298.

Blow, W.H. (1979): The Cainozoic Globigerinidae. A study of the morphology, taxonomy, evolutionary relationship and the stratigraphical distribution of some Globigerinidae (mainly Globigerinacea). - 3 vols., 1413 pp., E.J. Brill, Leiden, Netherlands.

BoudAGHER-FADEL, M.K. (2012): Biostratigraphic and geological significance of planktonic foraminifera. - Developments in Palaeontology \& Stratigraphy 22: 1-289.

Brinkhuis, H. \& ZaChariasse, W.J. (1988): Dinoflagellate cysts, sea level changes and planktonic foraminifers across the Cretaceous-Tertiary boundary at El Haria, Northwest Tunisia. - Mar. Micropaleontol. 13: 153-191.

BRÖNNIMANN, P. (1952): Globigerinidae from the Upper Cretaceous (Cenomanian-Maastrichtian) of Trinidad. - Bull. Amer. Paleontology 34 (140): 1-30.

Brönnimann, P. (1953): Note on planktonic foraminifera from Danian localities. - Bull. Amer. Paleontology 45: 339-341.

Brotzen, F. \& Pozaryska, T. (1961): Foraminifères du Paléocène et de l'Éocène inférieur en Pologne septentrionale; remarques paléogéographiques. - Rev. Micropaléontol. 4: $155-166$.

Canudo, J.I., Keller, G. \& Molina, E. (1991): Cretaceous/ Tertiary boundary extinction pattern and faunal turnover at Agost and Caravaca, SE Spain. - Mar. Micropaleontol. 17: 319-341.

Cushman, J.A. (1927): An outline of a re-classification of the Foraminifera. - Contributions from the Cushman Foundation for Foraminiferal Research 3: 1-105.

Delage, Y. \& Hérouard, E. (1896): Traité de Zoologie Concrète, vol. 1, La Cellule et les Protozoaires. - Schleicher Frères, Paris.

D'Hondt, S.L. (1991): Phylogenetic and stratigraphic analysis of earliest Paleocene biserial and triserial planktonic foraminifera. - J. Foramin. Res. 21: 168-181.

EICHWALD, C.E., VON (1830): Zoologia specialis. - Vilnae: D.E. Eichwaldus 2: 1-323.

FordhaM, B.G. (1986): Miocene-Pleistocene planktic foraminifers from D.S.D.P. Sites 208 and 77, and phylogeny and classification of Cenozoic species. - Evolutionary Monographs 6: 200 pp., University of Chicago.

Gradstein, F.M., Ogg, J.G., Schmitz, M.D. \& OGg, G.M. (2012): The Geological Time Scale. - Elsevier, 2 vols, 1144 p.

Hammer, Ø., Harper, D.A.T. \& Ryan, P.D. (2001): PAST: Paleontological Statistics Software Package for Education and Data Analysis. - Palaeontol. Electronica 4 (1): 9 p. 
Haque, A.F.M.M. (1956): The smaller Foraminifera of the Ranikot and the Laki of the Nammal Gorge, Salt Range. - Paleontol. Pakistanica, Geol. Surv. Pakistan 1: 1-300.

Hofker, J. (1978): Analysis of a large succession of samples through the Upper Maastrichtian and the Lower Tertiary of Drill Hole 47.2, Shatsky Rise, Pacific, Deep Sea Drilling Projet. - J. Foramin. Res. 8: 46-75.

KHAlilov, D.M. (1956): O pelagicheskoy faune foraminifer Paleogenovykh otlozheniy Azerbaydzana. - Trudy Instituta Geologii, Akademiya Nauk Azerbaydzhanskoy S S.R., Baku 17: 234-261.

Koutsoukos, E.A. (2014): Phenotypic plasticity, speciations, and phylogeny in Early Danian planktic foraminifera. - J. Foramin. Res. 44 (2): 109-142.

LI, Q. (1987): Origin, phylogenetic development and systematic taxonomy of the Tenuitella plexus (Globigerinitidae, Globigerinina). - J. Foramin. Res. 17: 295-320.

LI, Q. \& RADFORD, S.S. (1991): Evolution and biogeography of Paleogene microperforate planktonic foraminifera. - Palaeogeogr. Palaeoclimatol. Palaeoecol. 83: 87-115.

Li, Q., McGowran, B. \& Boersma, A. (1995): Early Paleocene Parvularugoglobigerina and late Eocene Praetenuitella: does evolutionary convergence imply similar habitat?. - J. Micropaleontol. 14: 119-134.

Liu, C. \& Olsson, R.K. (1992): Evolutionary radiation of microperforate planktonic foraminifera following the $\mathrm{K} / \mathrm{T}$ mass extinction event. - J. Foramin. Res. 22: 328-346.

Liu, C. \& Olsson, R.K. (1994): On the origin of Danian normal perforate planktonic foraminifera from Hedbergella. J. Foramin. Res. 24: 61-74.

Loeblich, A.R., JR. \& TAppan, H. (1987): Foraminiferal general and their clasification. - Van Nostrand Reinhold Company, New York, 2 vol., 970 p., 847 plates.

Luterbacher, H.P. \& Premoli Silva, I. (1964): Biostratigraphy of the Cretaceous-Tertiary boundary in Central Apennines. - Riv. Ital. Paleontol. S. 70: 67-128 (in Italian).

Molina, E., Arenillas, I. \& Arz, J.A. (1998): Mass extinction in planktic foraminifera at the Cretaceous/Tertiary boundary in subtropical and temperate latitudes. - B. Soc. Geol. Fr. 169: 351-363.

Molina, E., Alegret, L., Arenillas, I., Arz, J.A., Gallala, N., Hardenbol, J., von Salis, K., Steurbaut, E., VanDenberghe, N. \& Zaghbib-Turki, D. (2006): The Global Stratotype Section and Point of the Danian Stage (Paleocene, Paleogene, "Tertiary", Cenozoic) at El Kef, Tunisia: original definition and revision. - Episodes 29 (4): 263-278.

Molina, E., Alegret, L., Arenillas, I., Arz, J.A., Gallala, N., Grajales-Nishimura, M., Murillo-Muñetón,
G. \& ZaGhBiB-Turki, D. (2009): The Global Boundary Stratotype Section and Point for the base of the Danian Stage (Paleocene, Paleogene, "Tertiary”, Cenozoic): auxiliary sections and correlation. - Episodes 32 (2): 84-95.

Montanaro-Galliteli, E. (1957): A revision of the foraminiferal Family Heterohelicidae. - Stud. Foramin., US Nat. Mus. Bull. 215: 133-154.

Olsson R.K. (1970): Planktonic foraminifera from base of Tertiary Millers Ferry, Alabama. - J. Paleontol. 44: 598-604.

Olsson, R.K., Hemleben, C., Berggren, W.A. \& LiU, C. (1992): Wall texture classification of planktonic foraminifera genera in the Lower Danian. - J. Foramin. Res. 22: $195-213$.

Olsson, R.K., Liu, C. \& van Fossen, M. (1996): The Cretaceous-Tertiary catastrophic event at Millers Ferry, Alabama. - Geol. Soc. Am. S. 307: 263-277.

Olsson, R.K., Hemleben, C., Berggren, W.A. \& Huber, B.T. (1999): Atlas of Paleocene Planktonic Foraminifera. Smith. C. Paleob. 85: 1-252.

Papú, O.H., Prámparo, M.B., Náñez, C. \& Concheyro, A. (2000): Palinología y micropaleontología de la Formación Jagüel (Maastrichtiano-Daniano), perfil Opaso, Cuenca Neuquina, Argentina. - In: Simposio Paleógeno de América del Sur (Buenos Aires, 1996), Actas. - Servicio Geológico Minero Argentino, Anales 33: 17-31.

Salaj, J. (1986): The new Postrugoglobigerina praedaubjergensis Zone at the base of the stratotype of the marine Paleocene (El Kef, Tunisia). - Geol. Carpath. 37: 35-58.

Sмiт, J. (1982): Extinction and evolution of planktonic foraminifera after a major impact at the Cretaceous/Tertiary boundary. - Geol. Soc. Am. S. 190: 329-352.

SMIT, J. (1990): Meteorite impact, extinctions and the Cretaceous-Tertiary Boundary. - Geol. Mijnbouw 69: 187-204.

SMIT, J. (1999): The global stratigraphy of the Cretaceous-Tertiary Boundary impact ejecta. - Ann. Rev. Earth Pl. Sc. 27: 75-113.

Smit, J. \& Romein, A.J.T. (1985): A sequence of events across the Cretaceous-Tertiary boundary. - Earth Planet. Sci. Lett. 74: 155-170.

Subbotina, N.N. (1953): Iskopaemye Foraminifery SSSR. Globigerinidy, Khantkeninidy i Globorotaliidy. - Trudy Vsesoyuzhnyy Neftyanoy Nauchno-issledovatel'skiy Geologo-razvedochnogo Instituta (VNIGRI), Mikrofauna SSSR Sbornik 6, 76: 1-296.

Toumarkine, M. \& Luterbacher, H.P. (1985): Paleocene and Eocene planktic foraminifera. - In: Bolli, H.M., Saunders, J.B. \& Perch-Nielsen, K. (eds): Plankton Stratigraphy. - Cambridge University Press, 88-153. 


\section{Explanation of the plates}

\section{Plate 1}

Scanning electron photographs of Parvularugoglobigerina and Palaeoglobigerina species (scale bar $=100 \mu \mathrm{m})$.

Fig. 1. Palaeoglobigerina alticonusa, holotype, Zone P $\alpha$, DSDP Site 152, Caribbean Pacific (SEM-micrograph from Li et al. 1995). Fig. 2. Palaeoglobigerina alticonusa, sample KF16.50 (4.5 m above the K/Pg boundary), middle part of the E. simplicissima Subzone (Pv. eugubina Zone), El Kef, Tunisia.

Fig. 3. Palaeoglobigerina alticonusa, sample KF16.50 (4.5 m above the K/Pg boundary), middle part of the E. simplicissima Subzone (Pv. eugubina Zone), El Kef, Tunisia.

Fig. 4. Palaeoglobigerina fodina, holotype, Zone P $\alpha$, DSDP Leg 6, South Pacific (SEM-micrographs from BLow, 1979).

Fig. 5. Palaeoglobigerina fodina, sample STW $+50+52(0.5 \mathrm{~m}$ above the K/Pg boundary), upper part of the Pv. longiapertura Subzone (G. cretacea Zone), Ain Settara, Tunisia.

Fig. 6. Palaeoglobigerina fodina, sample KF15.00 (3 m above the K/Pg boundary), lower part of the E. simplicissima Subzone (Pv. eugubina Zone), El Kef, Tunisia.

Fig. 7. Palaeoglobigerina minutula, holotype, Pv. eugubina Zone, Ceselli, Italia (Luterbacher \& Premoli-Silva, 1964).

Fig. 8. Palaeoglobigerina minutula, sample STW 86 (2.6 m above the K/Pg boundary), lower part of the E. simplicissima Subzone (Pv. eugubina Zone), Ain Settara, Tunisia.

Fig. 9. Palaeoglobigerina minutula, sample STW84.2 (0.8 m above the K/Pg boundary), lower part of the Pv. sabina Subzone (Pv. eugubina Zone), Ain Settara, Tunisia.

Fig. 10. Palaeoglobigerina luterbacheri, holotype, sample KF15.00 (3 m above the K/Pg boundary), lower part of the E. simplicissima Subzone (Pv. eugubina Zone), El Kef, Tunisia.

Fig. 11. Parvularugoglobigerina longiapertura, holotype, Zone P $\alpha$, DSDP Leg 6, South Pacific (SEM-micrographs from BLOw, 1979). Fig. 12. Parvularugoglobigerina longiapertura, sample STW84.2 (0.8 m above the K/Pg boundary), lower part of the Pv. sabina Subzone (Pv. eugubina Zone), Aïn Settara, Tunisia.

Fig. 13. Parvularugoglobigerina longiapertura, sample KF14.00 (2 m above the K/Pg boundary), lower part of the $P v$. sabina Subzone (Pv. eugubina Zone), El Kef, Tunisia.

Fig. 14. Parvularugoglobigerina perexigua, holotype, Zone P $\alpha$, DSDP Site 152, Caribbean Pacific (SEM-micrograph from Li et al. 1995).

Fig. 15. Parvularugoglobigerina perexigua, sample El4.50 (3.5 m above the K/Pg boundary), lower part of the Pv. sabina Subzone ( $P v$. eugubina Zone), Elles, Tunisia.

Fig. 16. Parvularugoglobigerina sabina, holotype, Pv. eugubina Zone, Ceselli, Italia (Luterbacher \& Premoli-Silva, 1964).

Fig. 17. Parvularugoglobigerina sabina, sample El6.00 ( $5 \mathrm{~m}$ above the K/Pg boundary), upper part of the Pv. sabina Subzone (Pv. eugubina Zone), Elles, Tunisia.

Fig. 18. Parvularugoglobigerina eugubina, holotype, Pv. eugubina Zone, Ceselli, Italia (Luterbacher \& Premoli-Silva, 1964).

Fig. 19. Parvularugoglobigerina eugubina, sample STW87 (3.6 m above the K/Pg boundary), middle part of the E. simplicissima Subzone (Pv. eugubina Zone), Aïn Settara, Tunisia,

Fig. 20. Parvularugoglobigerina eugubina, sample STW87 (3.6 m above the K/Pg boundary), middle part of the E. simplicissima Subzone (Pv. eugubina Zone), Ain Settara, Tunisia. 


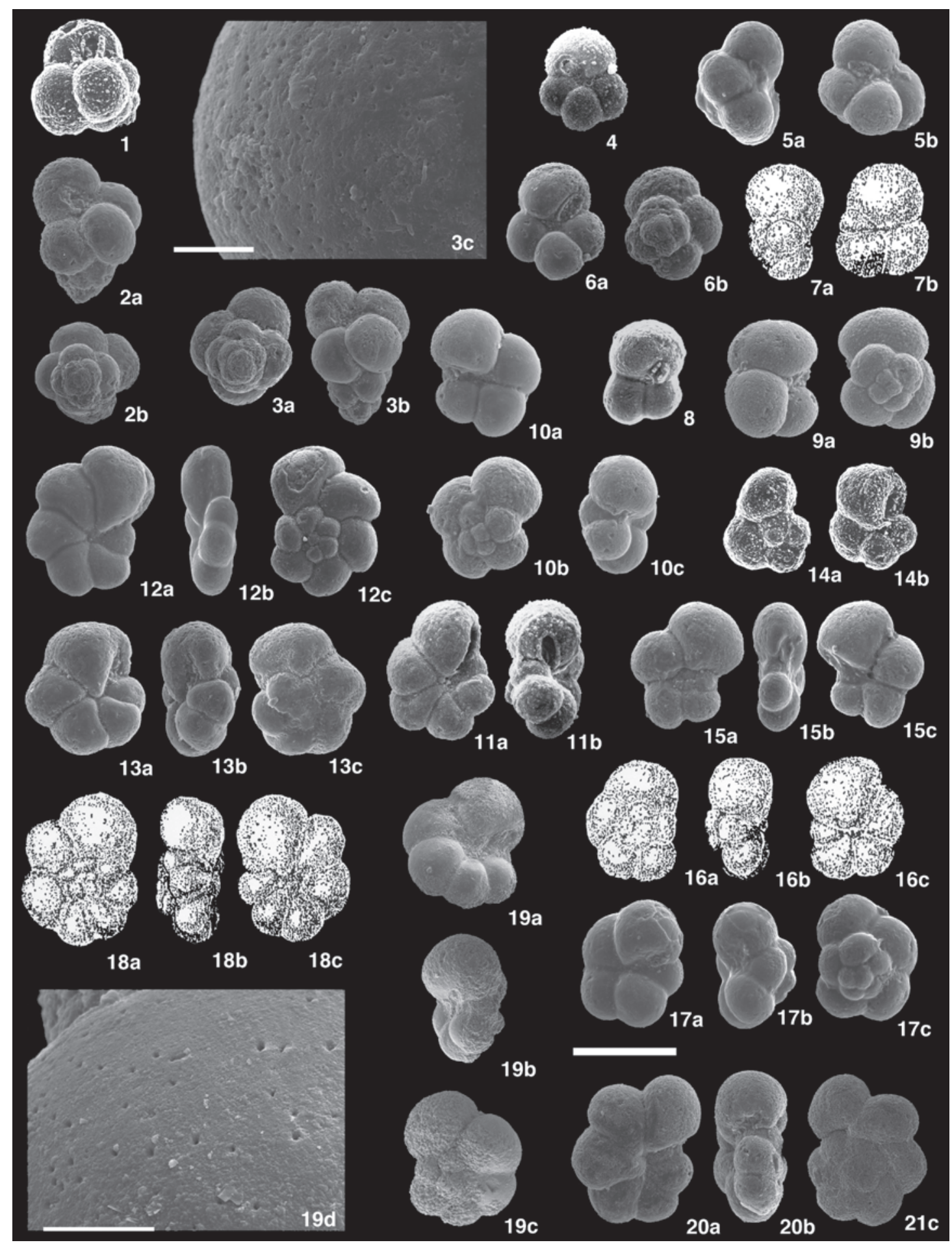


Plate 2

Scanning electron micrographs of Trochoguembelitria species (scale bar $=100 \mu \mathrm{m}$ ).

Fig. 1. Trochoguembelitria alabamensis, holotype, from Millers Ferry, Alabama, U.S.A. (SEM-micrograph from LiU \& OLsson, 1992).

Fig. 2. Trochoguembelitria alabamensis, sample KF24.80 (12.8 m above the K/Pg boundary), lower part of the $S$. triloculinoides Subzone (P. pseudobulloides Zone), El Kef, Tunisia.

Fig. 3. Trochoguembelitria alabamensis, sample STW87 (3.6 m above the K/Pg boundary), middle part of the E. simplicissima Subzone (Pv. eugubina Zone), Aïn Settara, Tunisia.

Fig. 4. Trochoguembelitria alabamensis, sample KF20.50 ( $8.5 \mathrm{~m}$ above the K/Pg boundary), middle part of the E. trivialis Subzone (P. pseudobulloides Zone), El Kef, Tunisia.

Fig. 5. Trochoguembelitria extensa, holotype, Zone P1, DSDP Leg 6, South Pacific (SEM-micrographs from BLow, 1979).

Fig. 6. Trochoguembelitria extensa, paratype, Zone P1, DSDP Leg 6, South Pacific (SEM-micrographs from BLOw, 1979).

Fig. 7. Trochoguembelitria extensa, sample KF18.50 (6.5 m above the K/Pg boundary), upper part of the E. simplicissima Subzone ( $P v$. eugubina Zone), El Kef, Tunisia.

Fig. 8. Trochoguembelitria extensa, sample KF18.50 (6.5 m above the K/Pg boundary), upper part of the E. simplicissima Subzone ( $P v$. eugubina Zone), El Kef, Tunisia.

Fig. 9. Trochoguembelitria extensa, sample KF18.50 (6.5 m above the K/Pg boundary), upper part of the E. simplicissima Subzone (Pv. eugubina Zone), El Kef, Tunisia.

Fig. 10. Specimen of Trochoguembelitria liuae sp. nov. of Olsson et al. (1999), assigned to Parvularugoglobigerina eugubina.

Fig. 11. Trochoguembelitria liuae sp. nov., sample KF18.50 (6.5 m above the K/Pg boundary), upper part of the E. simplicissima Subzone (Pv. eugubina Zone), El Kef, Tunisia.

Fig. 12. Trochoguembelitria liuae sp. nov., sample KF18.50 (6.5 m above the K/Pg boundary), upper part of the E. simplicissima Subzone (Pv. eugubina Zone), El Kef, Tunisia.

Fig. 13. Trochoguembelitria olssoni sp. nov., sample KF17.50 (5.5 m above the K/Pg boundary), lower part of the E. simplicissima Subzone (Pv. eugubina Zone), El Kef, Tunisia.

Fig. 14. Trochoguembelitria olssoni sp. nov., sample KF18.50 (6.5 m above the K/Pg boundary), upper part of the E. simplicissima Subzone (Pv. eugubina Zone), El Kef, Tunisia. 


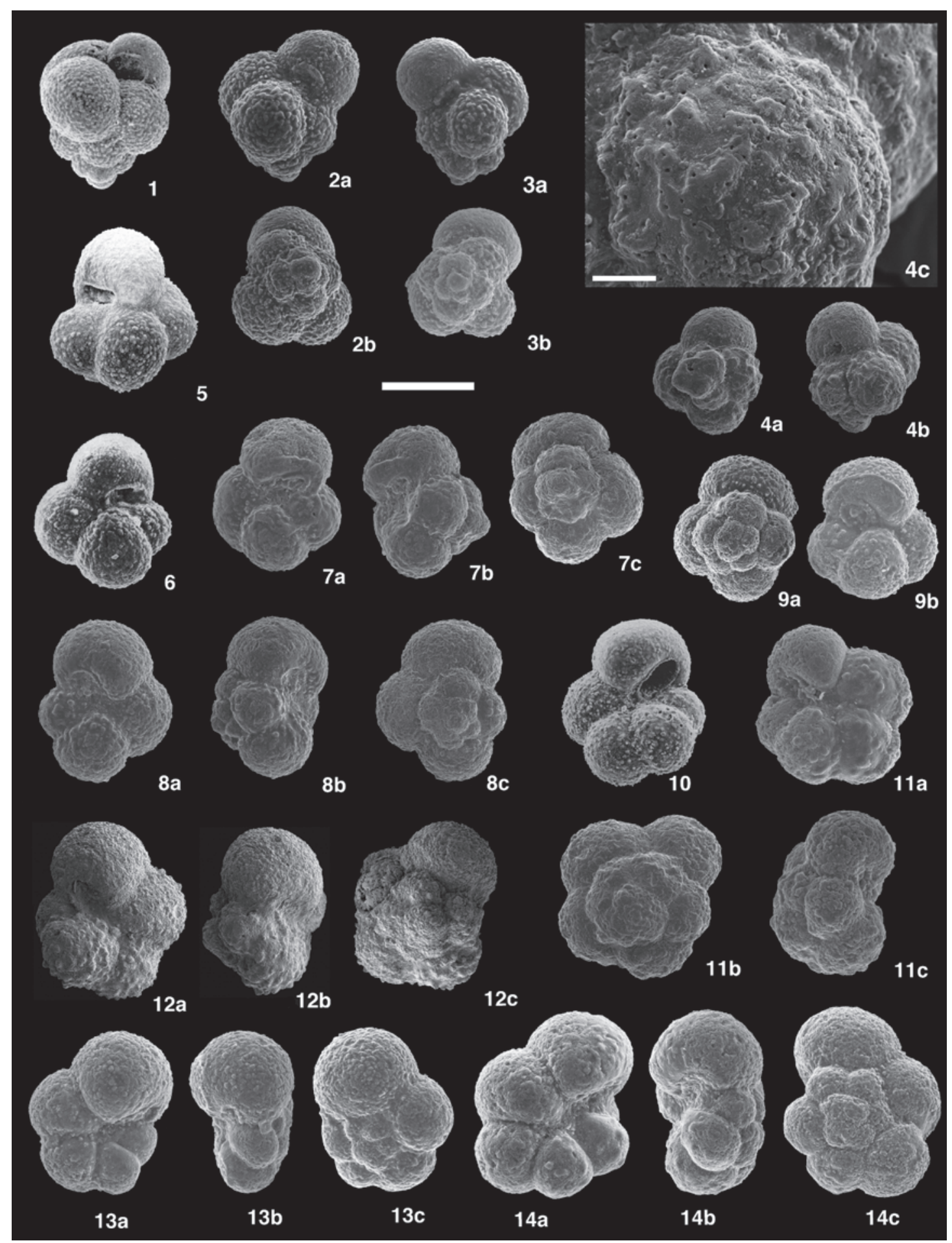


Plate 3

Scanning electron micrographs of the type-specimens of Trochoguembelitria liuae sp. nov. (scale bar $=100 \mu \mathrm{m}$ ).

Fig. 1. Trochoguembelitria liuae sp. nov., holotype MPZ 2014/295, sample KF20.50 (8.5 m above the K/Pg boundary), middle part of the E. trivialis Subzone (P. pseudobulloides Zone), El Kef, Tunisia.

Fig. 2. Trochoguembelitria liuae sp. nov., paratype MPZ 2014/296, sample KF18.50 (6.5 m above the K/Pg boundary), upper part of the E. simplicissima Subzone (Pv. eugubina Zone), El Kef, Tunisia.

Fig. 3. Trochoguembelitria liuae sp. nov., paratype MPZ 2014/297, sample KF18.50 (6.5 m above the K/Pg boundary), upper part of the E. simplicissima Subzone (Pv. eugubina Zone), El Kef, Tunisia. 


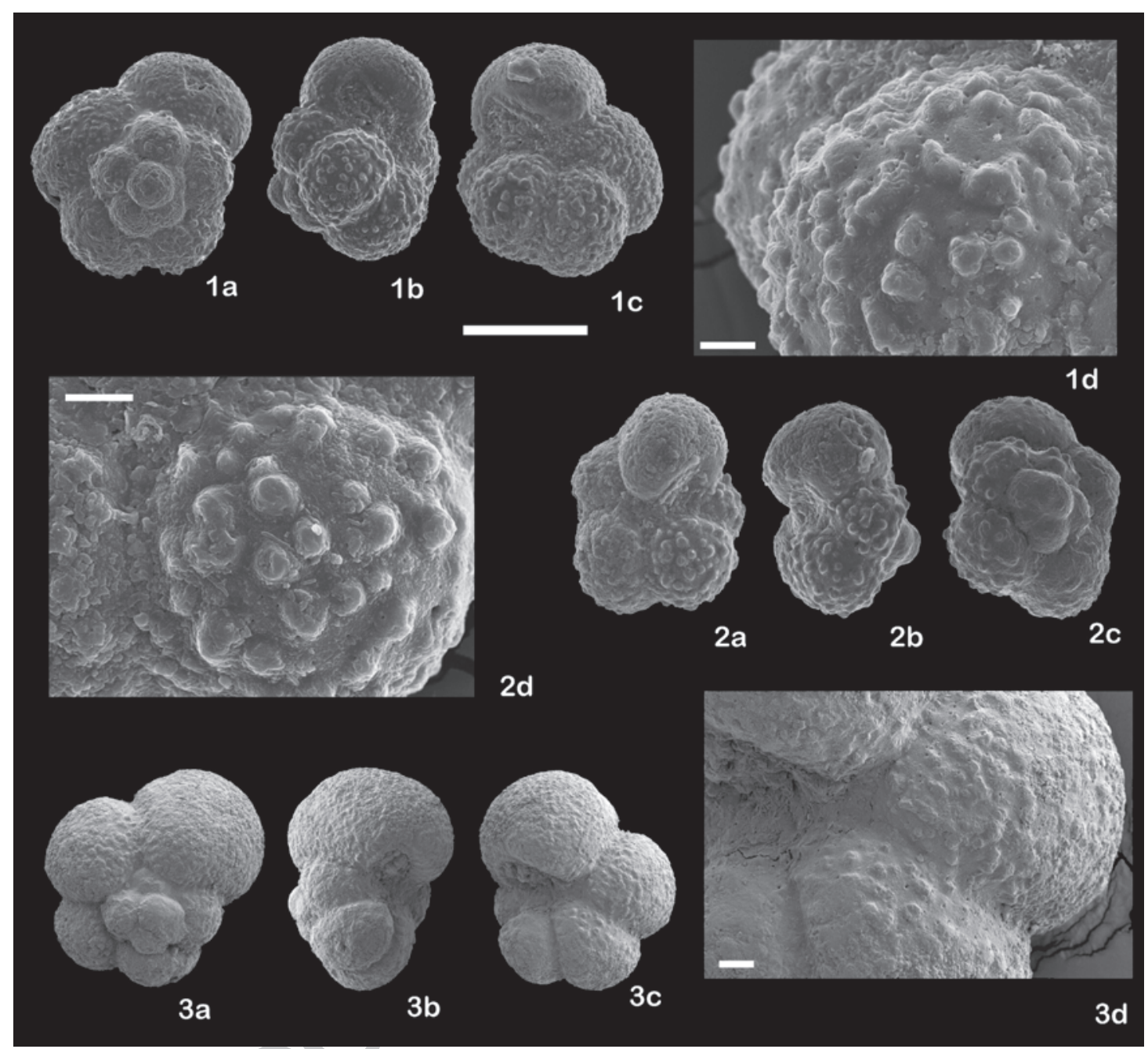


Plate 4

Scanning electron micrographs of the type-specimens of Trochoguembelitria olssoni sp. nov. (scale bar $=100 \mu \mathrm{m}$ ).

Fig. 1. Trochoguembelitria olssoni sp. nov., holotype MPZ 2014/298, sample KF20.50 (8.5 m above the K/Pg boundary), middle part of the E. trivialis Subzone (P. pseudobulloides Zone), El Kef, Tunisia.

Fig. 2. Trochoguembelitria olssoni sp. nov., holotype MPZ 2014/299, sample KF18.50 (6.5 m above the K/Pg boundary), upper part of the E. simplicissima Subzone (Pv. eugubina Zone), El Kef, Tunisia.

Fig. 3. Trochoguembelitria olssoni sp. nov., holotype MPZ 2014/300, sample KF18.50 (6.5 m above the K/Pg boundary), upper part of the E. simplicissima Subzone (Pv. eugubina Zone), El Kef, Tunisia. 

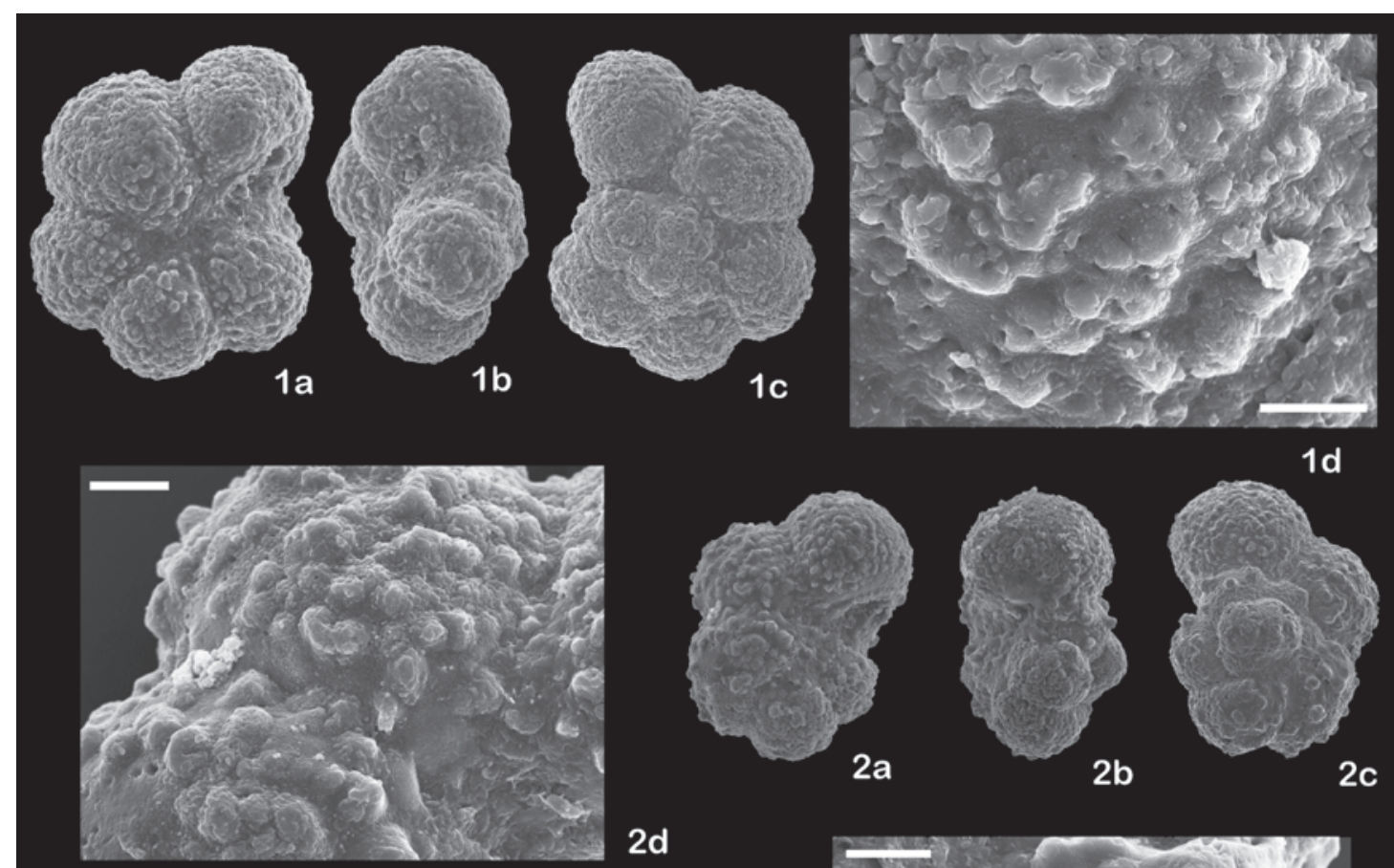

$2 d$
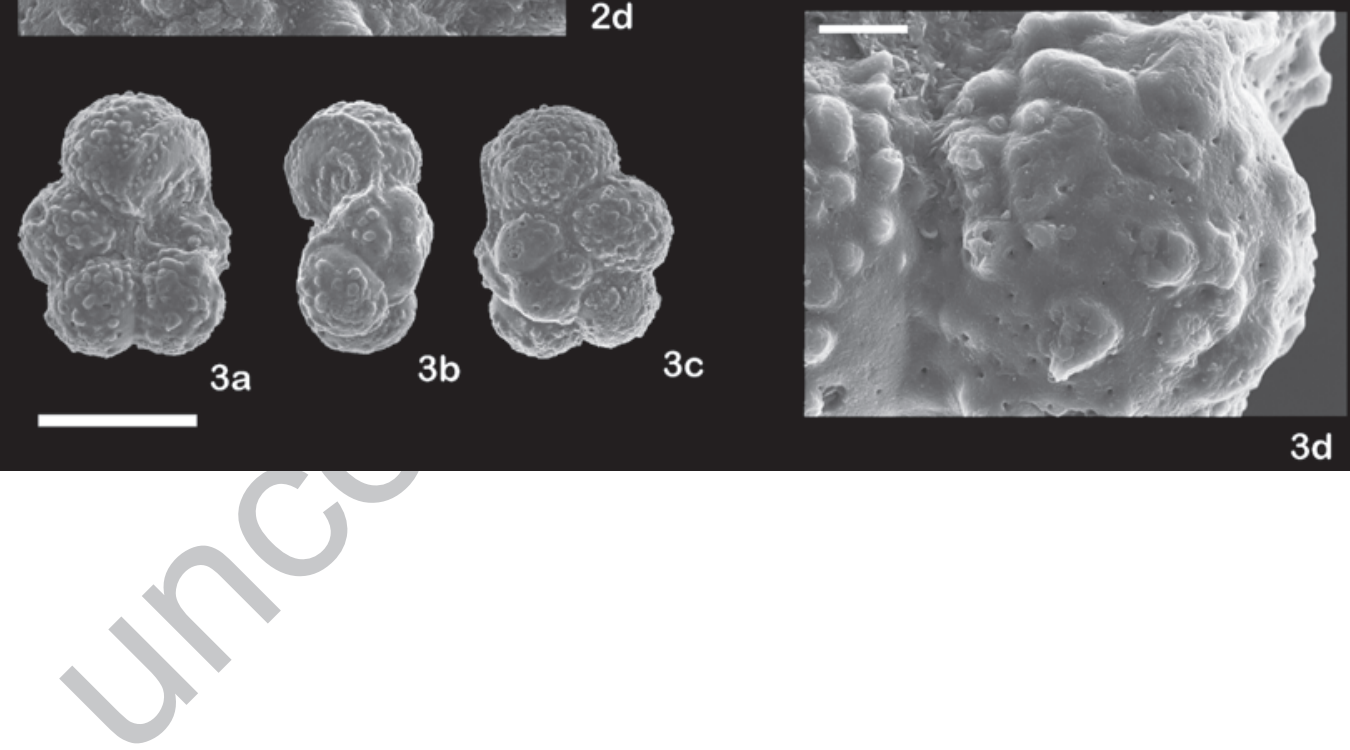


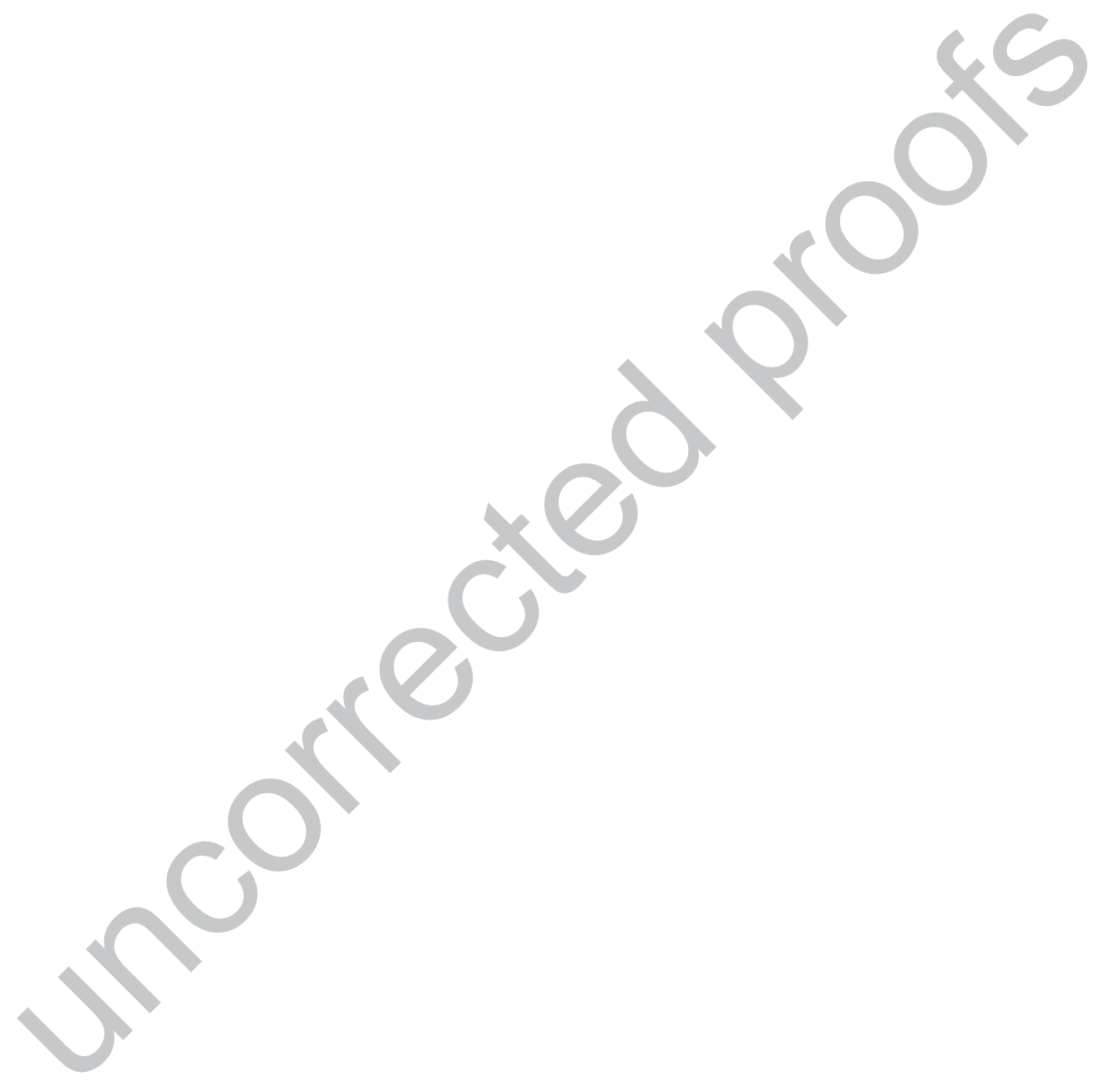

